\title{
The Miocene Depositional Geological Evolution of Phu Khanh, Nam Con Son and Tu Chinh - Vung May Basins in Vietnam Continental Shelf
}

\author{
Tran Thi Dung ${ }^{1}$, Tran Nghi ${ }^{2}$, Nguyen The Hung ${ }^{1}$, Dinh Xuan Thanh ${ }^{1}$, Pham Bao \\ Ngoc $^{3}$, Nguyen Thi Tuyen ${ }^{2}$, Tran Thi Thanh Nhan ${ }^{1}$, Nguyễn Thị Huyền Trang ${ }^{1}$ \\ ${ }^{I}$ VNU University of Science, 334 Nguyen Trai, Hanoi, Vietnam \\ ${ }^{2}$ Research Institute for Geoenviroment and Climate Change Adaption \\ ${ }^{3}$ Petroleum University, Petrovietnam
}

Received 23 March 2018

Revised 24 March 2018; Accepted 26 March 2018

\begin{abstract}
The geological development history of Miocene deposits in three sedimentary basins as Phu Khanh, Nam Con Son and Tu Chinh - Vung May is actually a depositional evolution in relation to sea level change and tectonic movement. The Miocene deposits in three basins were formed in three cycles corresponding to three depositional sequences: 1/ Early Miocene sequence: In this cycle, the tectonic setting of three basins is similar to one another, the terrain is less differentiated, the environment is mainly alluvial, coastal and shallow marine-bay. Topography of top Miocene surface was strongly deformed by the tectonic events such as compression, fault, fold that had created the rough relief and eroded unconformity surface. The product of erosion processes was supply of terrigenous depositional materials for early Miocene basins under the bay type. 2/ Middle Miocene sequence: The tectonic situation of three basins started changing. The basins were differentiated into 2 parts: The inner shelf with stable geological structure and dominated terrigenous deposits; The outer shelf was stronger subsidence the basin base topography was differentiated with the development of two sediment types: carbonate bearing terrigenous sediments and carbonate reefs. 3/ Late Miocene sequence: in this period the basins were differentiated into two distinct structural zones: the western zone with incline terrain, the dominated terrigenous sediments and the eastern zone with strong differentiated terrain, reef development they played the erosion zone role and supplied a large amount of biological clastic sediments to the shallow lagoons-bay.
\end{abstract}

Keywords: Sedimentary evolution, secondary basin, reconstructed, lithofacies.

\section{Introduction}

The Cenozoic sediments of the basins as Phu Khanh, Nam Con Son and Tu Chinh -

\footnotetext{
* Corresponding author. Tel.: 84-966097634.

Email: trannghi@vnu.edu.vn

https://doi.org/10.25073/2588-1094/vnuees.4236
}

Vung May are located in the deep sea water region, but from Eocene to Pliocene they were formed in continental, coastal, shallow marine and bay - lagoonal environments [1-3]. The paper is intended to present the geological evolution of Miocene deposits in these three basins (Figure 1). 


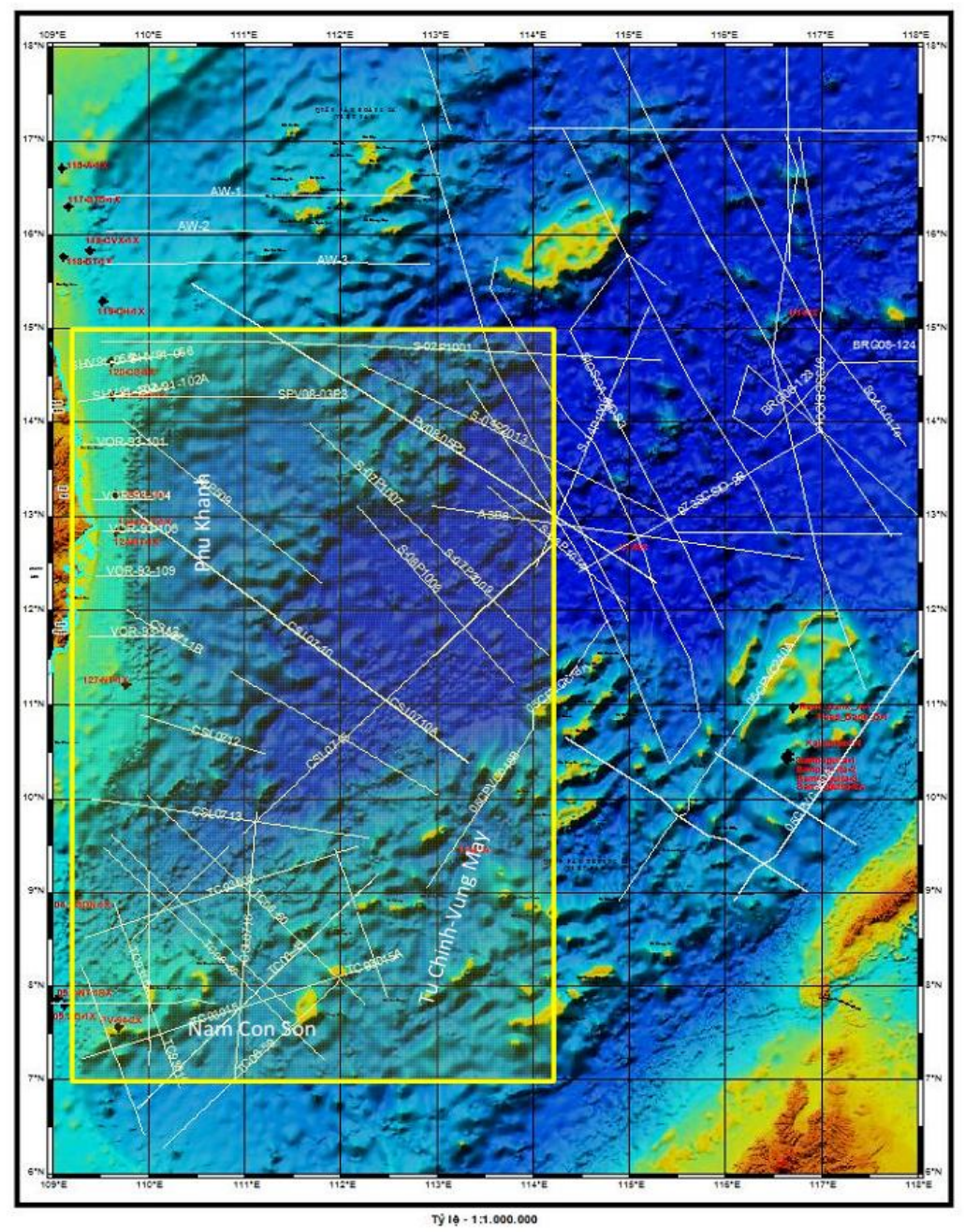

Figure 1. The location of Phu Khanh, Nam Con Son and Tu Chinh-Vung May basins with seismic lines and wells used in the study.

The study of depositional geological history is actually the reconstruction of lithofacies evolution picture in relationship to sea level change and tectonic movement. The lithofacies and geological structure through each period have a correlation of cause - consequence with each other [4-6]. Therefore, to do it, first it is necessary to build the geological structural maps for the secondary basins as early, middle and late Miocene periods. Based on those maps, the depositional facies with each depositional systems tract will be presented as: (1) Lowstand Systems Tract (LST); (2) Transgressive
Systems Tract; (3) Highstand Systems Tract by the rule of lithofacies association [7].

In America, Canada and western countries in the 1980's decade, a research tendency on basin analysis, sequence stratigraphy and correlaion between sedimentology and tectonic has been studied and published by many authors as Dickison et al., 1979; Gerhard, 1991; Posamentier, Jervey and Vail, 1988; Van Wagoner, Posamentier, Michum, et al, 1988; Emery and Myer, 1996; Catuneanu, 2007 [814]. Together with it, in Russia the sedimentologist Rukhin L. B (1969) has 
considered this relation as the lithofacies association and facies exchange in time and space [7]. The most important contribution of sequence stratigraphy is that it has determined the sequences based on the arrangement order of sedimentary units of the same origin in time and space with the cycle of eustatic sea level change. However the approach has still been limited. The authors have not much yet paid attention to the reconstruction of secondary basins deformed by geological events that occurred after the diagenesis stage such as fault, fold, high basement compression, volcanic eruption. This deformation has made the bedding of original depositional layers changed and therefore it has in somehow caused the misunderstanding on the real structure of sedimentary rocks and for example as term "parallel inclination structure" is due to deformation of original parallel horizontal structure of sedimentary rocks to be created because in sedimentology there has been no term "parallel inclination" structure [4]. If sedimentary supply source is overload and terrain is inclined, then sedimentary structure will have type of sigma or progressive wedge.

To reconstruct the geological history through the periods from early Miocene to late Miocene for the deep water sedimentary basins, it is well recognized on the relationship between the sedimentary cycles and tectonic cycles. The tectonic subsidence cycle of the secondary basins formed, and then the occurrence of normal faults developed together with depositional process. The period that the secondary basins was compressed and uplifted above sea level, occurred by the post deposional faults and eroded to create the boundaries of secondary basins. These boundaries have also coinsided with the sequence boundaries.

It is distinguish between 2 types of faults shown on the seismic section as single and double faults. The single fault is composed of thrust fault and linear strike-slip fault. The double fault includes 2 types: strike-slip fault and rotation fault occurred at the same time with fault surface in concave-bow shape as seen in Figures 2, 7, 8.

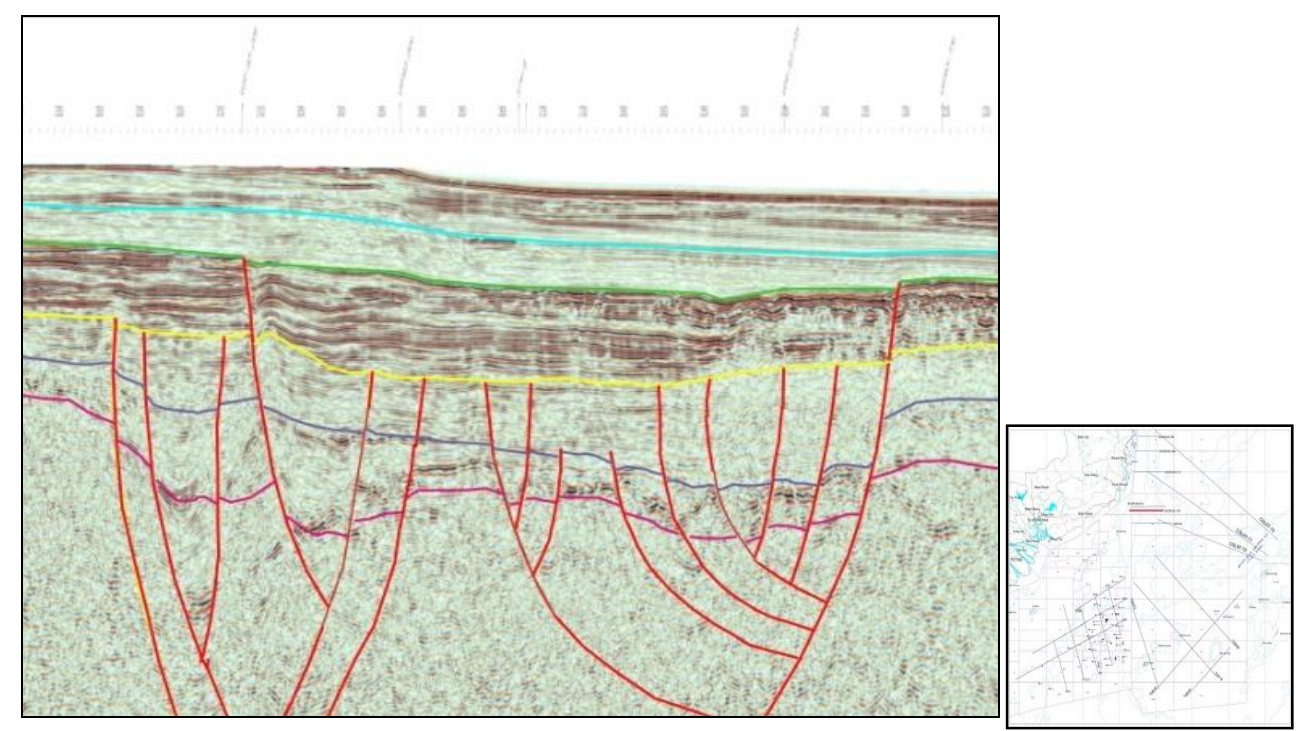

Figure 2. The fault systems were developed by subsidence and compression mechanism in the seismic line VOR93-116 (PVN source) 


\section{Material and methodology}

1- The method to divide the structure stages is to determine the boundaries vertically for the secondary basins. The boundaries between the Miocene secondary basins include: (1) boundary between upper Oligocene and lower Miocene $\left(\mathrm{E}_{3}{ }^{2}-\mathrm{N}_{1}{ }^{1}\right)$; (2) Boundary between lower Miocene and middle Miocene $\left(\mathrm{N}_{1}{ }^{1}-\mathrm{N}_{1}{ }^{2}\right)$ and (3) Boundary between middle Miocene and upper Miocene $\left(\mathrm{N}_{1}{ }^{2}-\mathrm{N}_{1}{ }^{3}\right)$. These boundaries were identified by reflection terminations of seismic sequences on the seismic sections, they were shown by unconformities or correlative conformities formed by sea level changes $[13,14]$.

2- The method to reconstruct the original secondary basins. The present secondary basins were strongly deformed after the diagenesis stage. The types of deformation could be seen as fault, fold and volcanic activities. To reconstruct the sedimentary geological sections of secondary basins, Tran Nghi (2005) proposed a formula to process the deformations as follow $[4,15]$ :

$$
\begin{aligned}
& \text { Lnt }=\sum_{i=1}^{n}\left(t_{1 i}+t_{2 i}\right)+\sum_{i=1}^{n}\left(n_{1 i}+n_{2 i}\right)+ \\
& \sum_{i=1}^{n}\left(u_{1 i}+u_{2 i}\right)+\sum_{i=1}^{n}\left(c_{1 i}+c_{2 i}\right)
\end{aligned}
$$

Where:

$t_{1 i}$ and $t_{2 i}$ is the length of hanging wall and foot wall of the i normal fault

$\mathrm{n}_{1 \mathrm{i}}$ and $\mathrm{n}_{2 \mathrm{i}}$ is the length of hanging wall and foot wall of the $i$ thrust fault

$\mathrm{u}_{1 \mathrm{i}}$ and $\mathrm{u}_{2 \mathrm{i}}$ is the length of two sizes of the triangle drown by the i fold

$c_{1 i}$ and $c_{2 i}$ is the length of hanging wall and foot wall of the normal fault in the i dip wing.

3- The method to establish the structure maps for each period

At present the geological structure maps for each geological formation are normally built, but the change of geological structure through each stage are not still paid yet. The procedure for reconstructing the secondary basins for the Miocene sedimentary formations are as follow $[16,17]$ :
- Reconstructing step by step for each primitive secondary basin $\left(\mathrm{N}_{1}{ }^{1}, \mathrm{~N}_{1}{ }^{2}, \mathrm{~N}_{1}{ }^{3}\right)$;

- Establishing the isopach map for each basin $\left(\mathrm{N}_{1}{ }^{1}, \mathrm{~N}_{1}{ }^{2}, \mathrm{~N}_{1}{ }^{3}\right)$ based on the reconstructed secondary basins;

- Establishing the original geological structure maps for three secondary basins $\left(\mathrm{N}_{1}{ }^{1}\right.$, $\mathrm{N}_{1}^{2}, \mathrm{~N}_{1}^{3}$ ).

4) The method to establish the lithofaciespaleogeographical maps for each period and for each depositional system tracts as LST, TST, HST $[6,14,18]$ :

- Localize the eroded zone for material supply and depositional area;

- Localize the lithofacies based on the facies association in space from erosion zone and accumulation zone to the central basin;

- Determine the ancient coastal line;

- Determine the direction of material supply;

- Determine the direction of bottom current transportation.

5) The method to determine the tectonostratigraphic complex based on the integrated analysis of data: lithofacies analysis, thin section analysis, seismic facies analysis and vertical structure stratum analysis [19].

- Early Miocene tectonostratigraphic complex composed of alluvial terrigenous sedimentary, deltaic, lagoon, shallow marine facies accumulated in bay-lagoonal basin situating between the islands that played role of eroded zone;

- Middle Miocene tectonostratigraphic complex include deltaic terrigenous, shallow marine, bay-lagoon and reef limestone facies with the stable tectonic mechanism;

- Late Miocene tectonostratigraphic complex include the mixture sedimentary facies in richness with biological debris. The sea bottom has been coral reef islands was uplifted, eroded and supplied a large amount of biological debris material. On the seismic 
profiles, sediments of this complex was expressed by white refrection wave fields.

\section{Study results}

\subsection{Concept of the secondary basin}

In Miocene sedimentary evolution of Phu Khanh, Nam Con Son and Tu Chinh - Vung May basins it was able to recognize three sedimentary cycles (early, middle, late Miocene); each cycle corresponds to two tectonic phases (subsidence and uplift) to create the unconformities, it was named the secondary basin $[5,6,11,17,18,20,21]$.

To make clear the geological evolution history of Miocene sedimentary basin, it is essential to build the structure maps for each secondary basin of early, middle, late Miocene periods [16, 22, 23].

Through each period, the uplift and subsidence blocks were changed that has made the structure strongly differentiated and created the secondary basin groups.

\subsection{Interpretation of reconstructed section of} the secondary basin a) Concept. According to the present structure of Phu khanh, Nam Con Son basins it can be divided into three structural zones: (1) Zone 1: The inner shelf with the water depth of $0-200 \mathrm{~m}$ belonging to shallow sea zone; (2) Zone 2: The central subsided zone with water depth of 500-2000m; (3) Zone 3: The outer shelf with depth of $2500-3000 \mathrm{~m}$ belonging to deep sea water. On the seismic section, the seismic wave field is basically different from the bottom upwards and from the margin outwards the center caused by two determinative factors: (1) the lithofacies change; (2) the tectonic movement. The configuration of geological structure and present depth of the section are the result of three continuously active processes: sedimentary process, sea level change and tectonic movement undergone $32 \mathrm{Ma}$ until now. Only Miocene stage, the reconstruction of the secondary sedimentary basins was considered as "a revolution" for deformation events as fault, fold, compression and volcanic activities (Figures 3, 4, 5, 6).

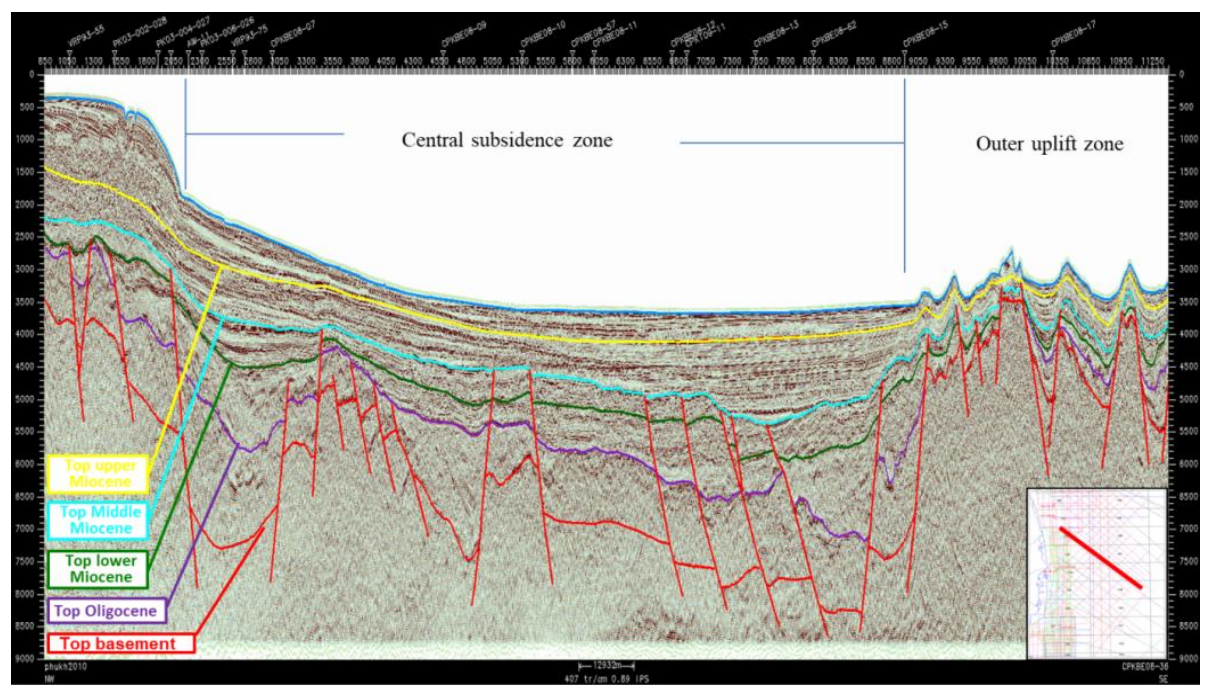

Figure 3. Seismic line PKBE08-36 run across Phu Khanh basin with interpreted Cenozoic sedimentary boundaries: red horizon - PreCenozoic top basement, violet - top Oligocene, green - top lower Miocene, blue top middle Miocene, yellow - top upper Miocene [24]. 
b) Determine the boundaries of the secondary basins: (1) the boundaries between late Oligocene - early Miocene, early Miocene middle Miocene are regional unconformities, but they were strongly deformed to separate to discontinuous surfaces; (2) The boundary between middle Miocene - late Miocene was created as a maker horizon by an angle unconformity with rough terrain surface in the entire Vietnam continental shelf due to the end of middle Miocene tectonic phase occurred rather strongly by blocky differentiation of $\mathrm{Tu}$ Chinh - Vung May basin and of middle zone and outer zone for Phu Khanh and Nam Con
Son basins; (3) The boundary between late Miocene and Pliocene - Quaternary was an eroded unconformity in the whole Vietnam continental shelf, mainly by uplift of sea bottom terrain above sea level, but no differentiated by blocks (Figure 3).c) Remarks about the change of the basin configuration on the seismic section before and after reconstruction as in the Figures 4, 5, 6. After reconstructing the dimension of middle Miocene basin is larger than early Miocen basin and the dimension of late Miocene is larger than middle Miocene basin. The younger basins were widened in the linear shape.
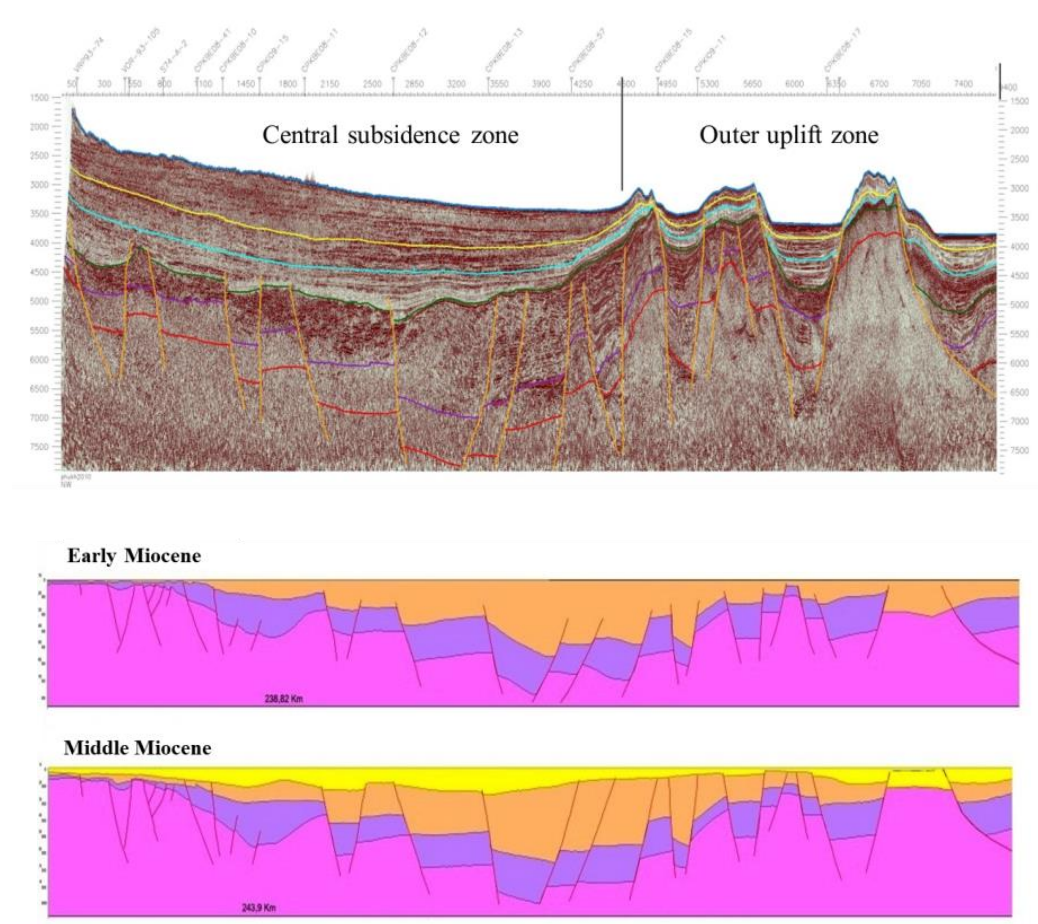

Late Miocene
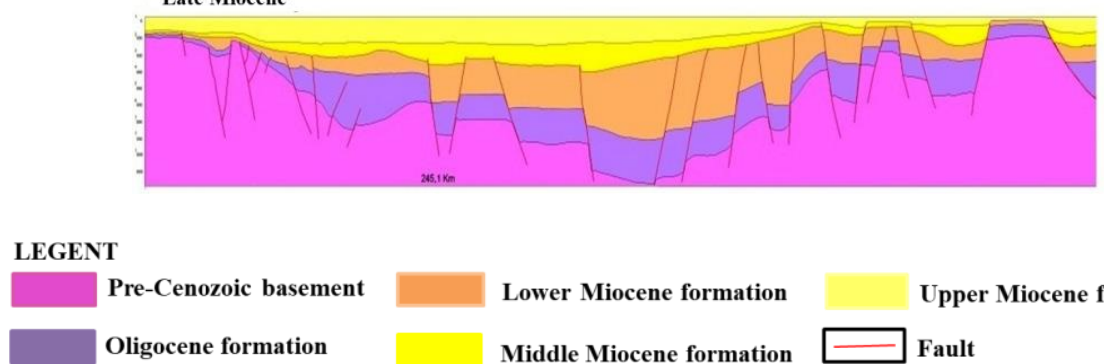

Lower Miocene formation Upper Miocene formation

Middle Miocene formation Fault

Figure 4. The reconstructed section of early, middle, late Miocene secondary basins on the seismic line CSL0710 in Phu Khanh basin. 

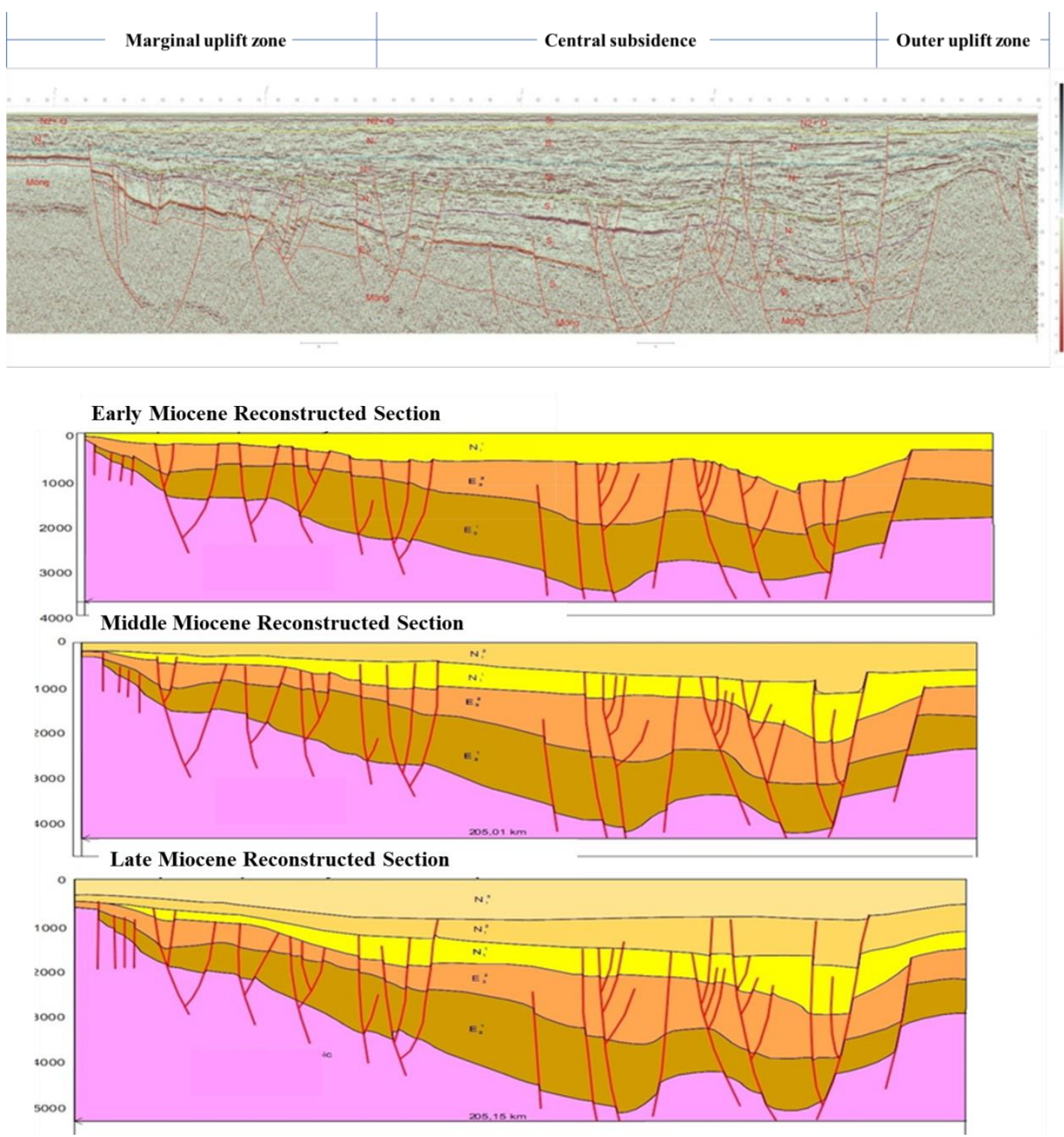

\section{LEGEND}
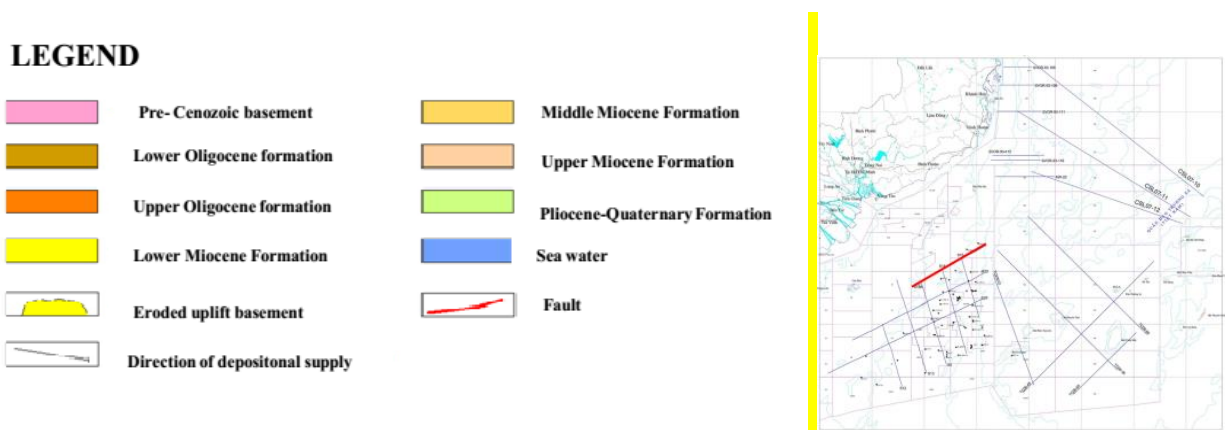

Figure 5. The reconstructed section of early, middle, late Miocene secondary basins on the seismic line S19 in Nam Con Son basin 


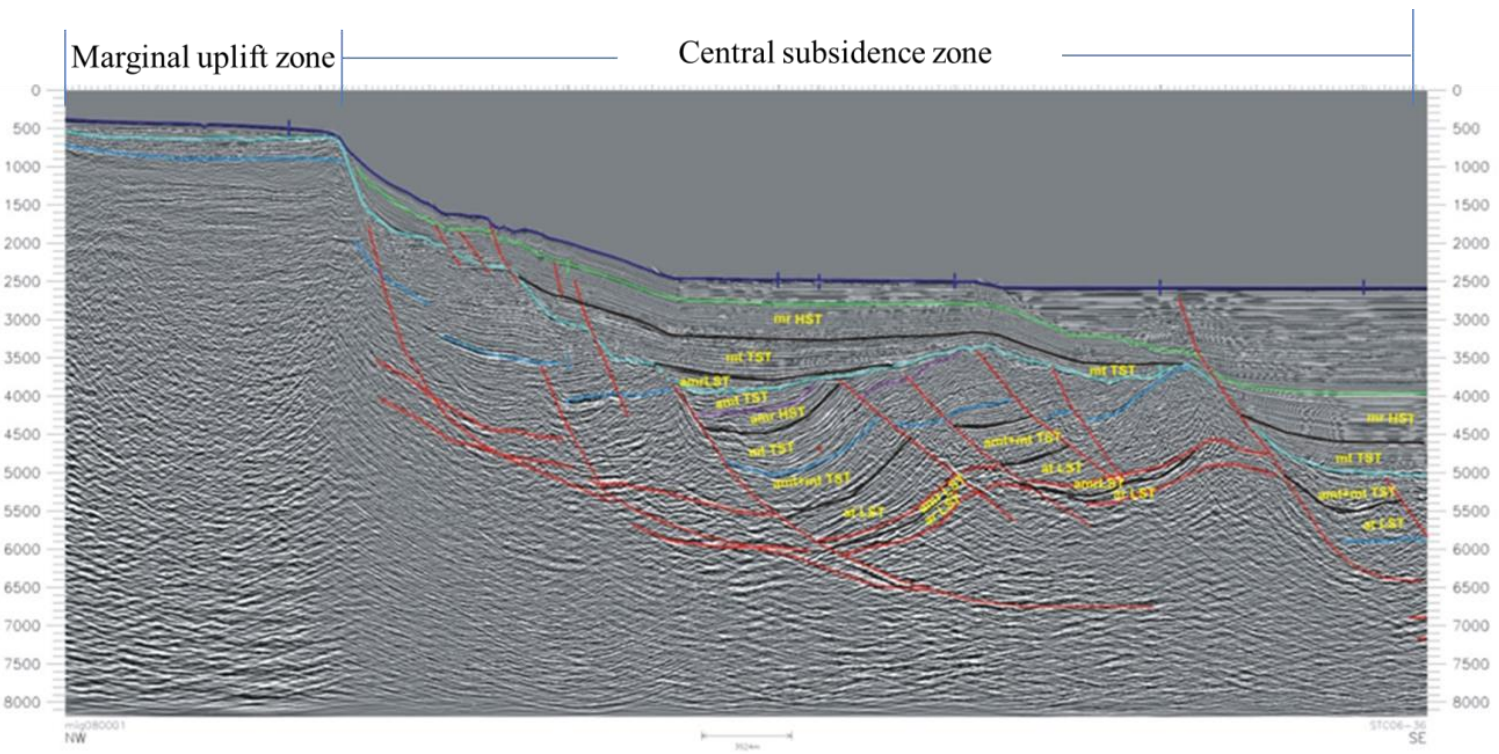

Early Miocene Reconstructed Section

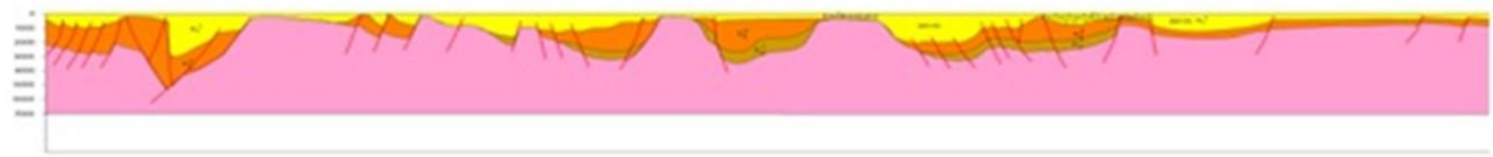

Middle Miocene Reconstructed Section

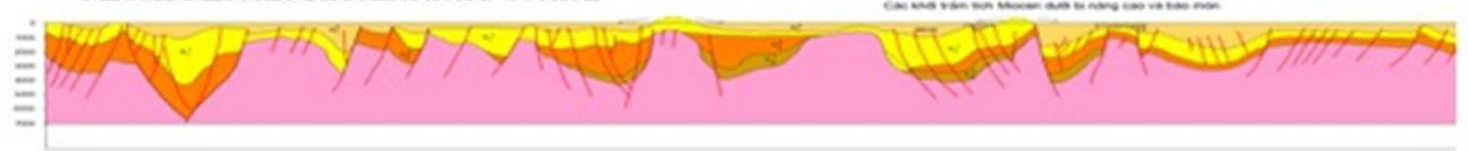

Late Miocene Reconstructed Section

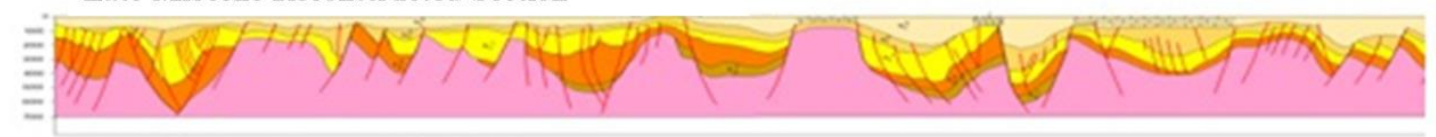

LEGEND
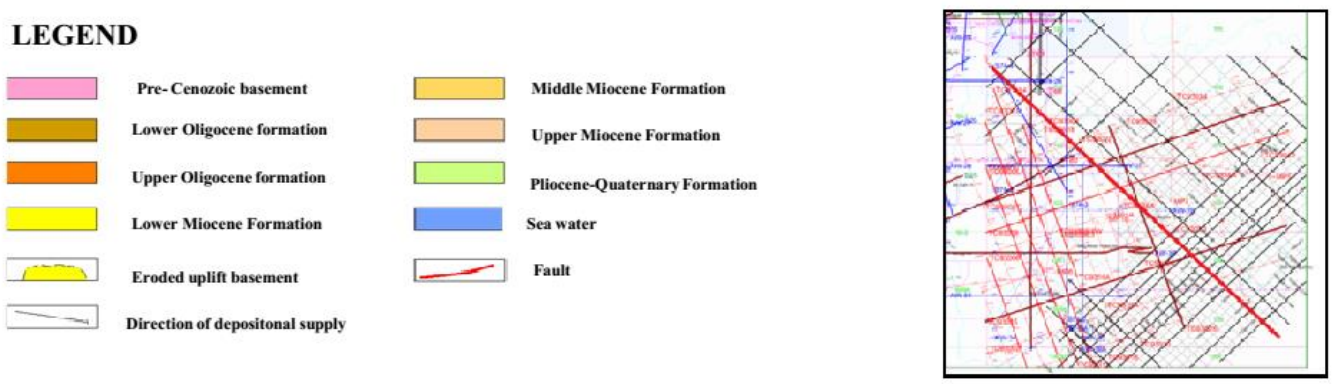

Figure 6. The reconstructed section of early, middle, late Miocene secondary basins on the seismic line STC06-36 in Tu Chinh - Vung May basin. 
By analysis of the above reconstructed sections in the figures $4,5,6$, it shows that:

- The present early Miocene secondary basin (before reconstruction) was deformed by strike-slip fault, fold and sag. The basin was widened in the linear shape;

- The present middle Miocene secondary basin was deformed by strike-slip fault, strikeslip and rotation fault, blocky differentiation compression. The basin was widened in the oval shape;

- The present late Miocene secondary basin was deformed by strike-slip fault and regional uplift compression. The basin was widened in the regular shape;
- From early Miocene to late Miocene the size of the basin was widened due to the extension thermal subsidence process.

On the seismic sections, secondary basins were shown by the following characteristics (Figures 7, 8):

- Angular unconformity between middle Miocene and late Miocene;

- The middle Miocene secondary basin was strongly deformed by strike-slip and rotation fault of level 2, inclinated wing normal fault of level 3, fold, sag;

- The late Miocene secondary basin was characterized by free seismic reflection wave field (white color) due to the deposits in richness of biological debris.

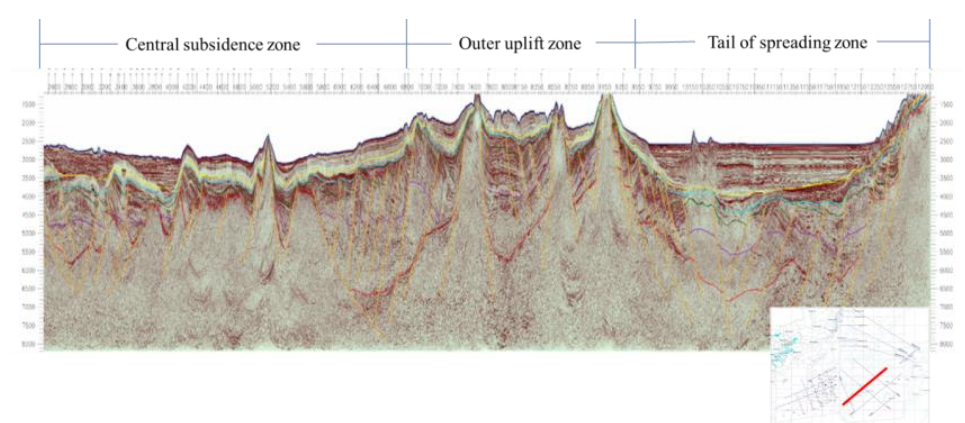

Figure 7. Interpreted seismic section of line STC06-44 in Tu Chinh-Vung May basin [13].

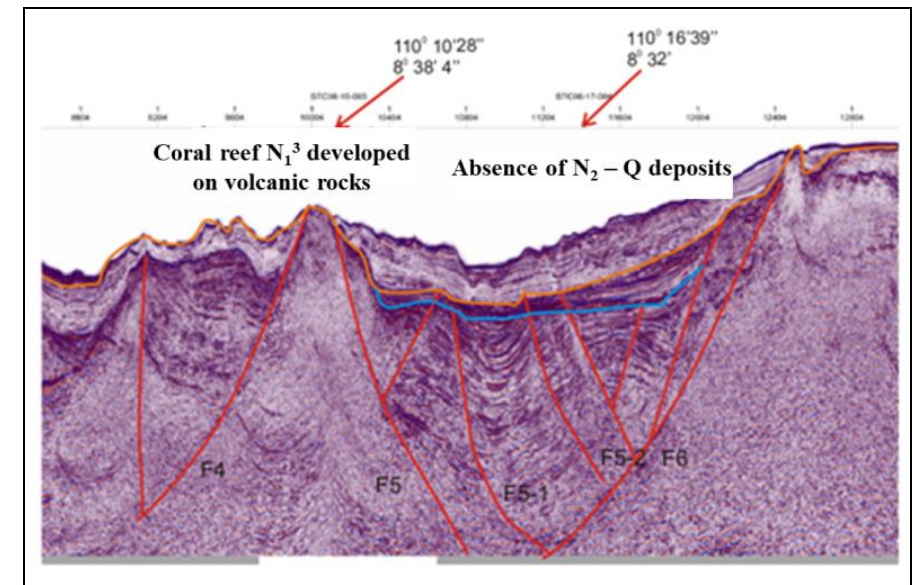

Figure 8. The section line STC06-36 of TC-VM basin with the presence of normal strike-slip fault, rotation fault, listric structure with 3 deformation phases: end of late Oligocene $\left(\mathrm{E}_{3}{ }^{2}\right)$, end of late middle Miocene $\left(\mathrm{N}_{1}{ }^{2}\right)$, end of late Miocene $\left(\mathrm{N}_{1}{ }^{3}\right)$.

Key note: 1) Angle unconformity surface of middle Miocene top; 2) Strike-slip and rotation fault with surface in concave-bow shape; 3) Inclination wing normal faults formed by compression and rotation activities 


\subsection{Depositional evolution in relation to tectonic activities}

Geological - depositional characteristics of early Miocene $\left(N_{l}{ }^{l}\right)$

The geological characteristics: In the early Miocene stage, geological structure of each basin basically differs on the configuration and direction of the axis for the uplift and subsided blocks. The syn-depositional fault systems were symmetric normal faults formed in the interior of the basins and being consequence of cyclic extension thermal subsidence due to melting process of Pre-Cenozoic continental crust under the impact of Mantle thermal convention [4, 15, 25].

In Phu Khanh basin, some deep and wide troughts were formed in the west of the basin. The other deep troughs with smaller area were distributed in the south and in the northeast on the weak subsidence ground and occupied

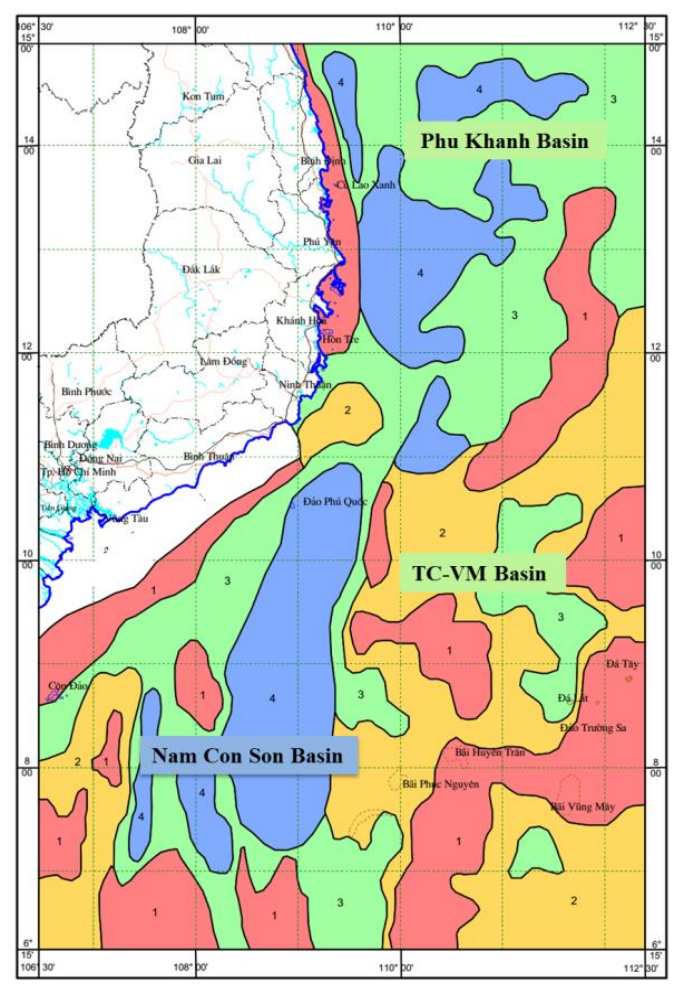

a) Schema of geological structure of early Miocene secondary basin. almost the area of the region. In this stage, the uplift zone has created a range running along the northeast-southwest direction. The syndepositional normal fault systems were distributed along the boundaries between high and low blocks in many different directions: (1) latitude; (2) northeast-southwest and (3) northwest -southeast (Figure 9a).

For the Nam Con Son basin, the subsided zone was distributed in the east and some smaller troughs in linear shape extended in the north-south and in the west of the basin. The uplift zone of Nam Con Son was the continental area located in the west-southwest. The weaker uplift blocks with smaller dimension were distributed in the west of the basin. The syndepositional fault system were distributed in three directions: (1) North-South, (2) Northeast - southwest, (3) West - East (Figure 9a).

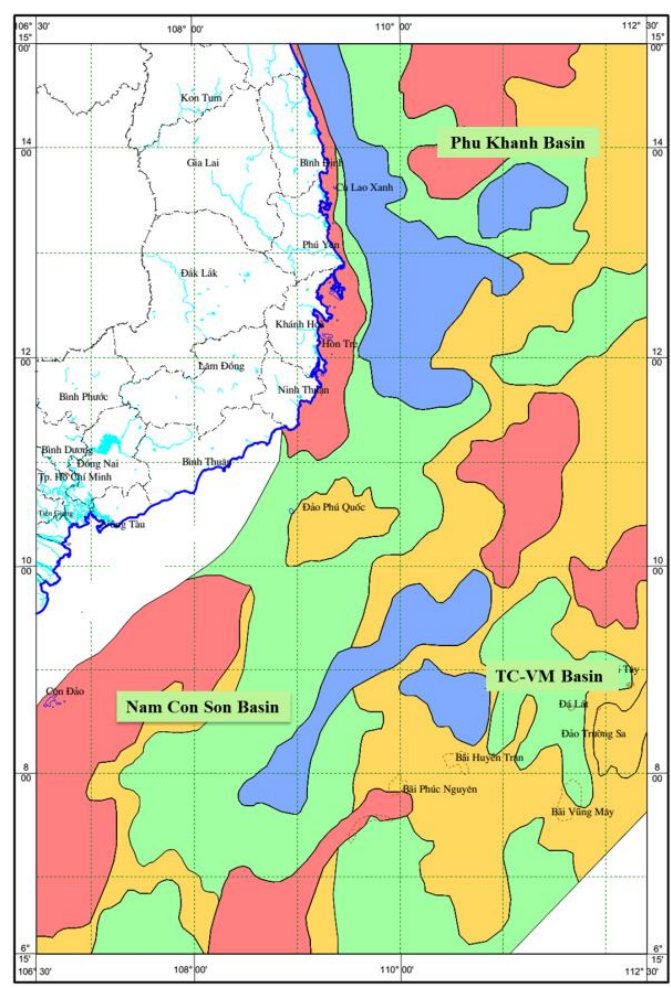

b) Schema of geological structure of middle Miocene secondary basin. 


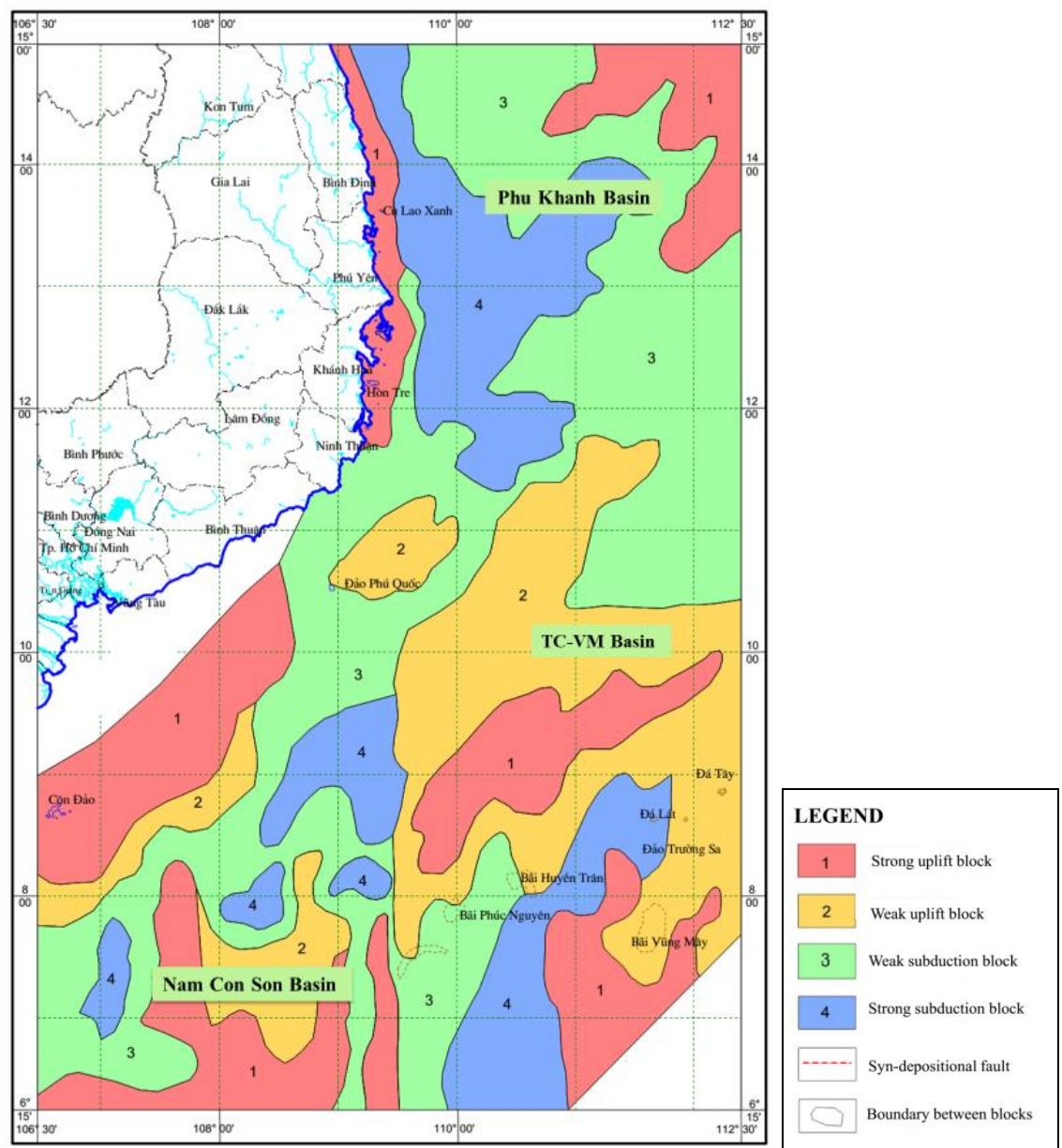

c) Schema of geological structure of late Miocene secondary basin.

Figure 9. Schema of geological structure of early, middle and late Miocene secondary basins in the Phu Khanh, Nam Con Son and Tu Chinh - Vung May basins.

For the Tu Chinh - Vung May basin, the uplift and subsided blocks has the structure of circular shape interlaced with fox skin type, exception in the southeastern zone where the formation of some strong uplift zones was extended in the northeast - southwest. The configuration and structure were shown by the results of three geological processes: (1) extension geothermal subsidence; (2) uplift compression and (3) strike - slip and rotation fault. The syndepositional fault systems had short lenght and connected with one another in polygon and concave configuration, the consequence of the extention thermal subsidence process (Figure 9a).

Sedimentary characteristics: In time interval from the beginning to the end of early Miocene stage, the depositional accumulation space was occupied in almost area of each basin, but the depositional facies distribution was different and changed. In this stage for three basins as Phu Khanh, Nam Con Son and Tu Chinh - Vung May basins, the terrigenous deposits were dominated. From the margin to the center of the basin the sedimentary thickness was gradually increased and reached to maximum in the center. It proved that the 
center was always laid next to the river mount where it brought the terrigenous materials to supply and shale sandy deltaic facies was dominated in the two depositional system tracts as LST and HST. However, in TST phase in the central area of three basins existed hydrolic lagoons that were convenient for accumulating the carboniferous clay (Figure 10,11). In three system tracts of early Miocene, the depositional accumulation space seems to be not changed. The area for supplying the terrigenous sedimentary materials for Phu Khanh basin was mainly located in the west of the basin and in the uplift zone in east southeast and for the Nam Con Son and Tu Chinh - Vung May basins it was derived from Sunda shelf and Nam Con Son uplift zone in the west and southwest. In time interval from the beginning to the end of early Miocene, the area of distribution of marginal alluvial sandy silt facies was lessened, meanwhile the area of distribution of carboniferous clay, dolomite and clay facies in richness of shallow marine and lagoon organic matter were gradually increased and reached the maximum area at the end of maximum transgressive phase.

\begin{tabular}{|c|c|c|c|c|c|c|c|c|c|c|}
\hline \multirow{2}{*}{$\begin{array}{c}\text { Secondary } \\
\text { Basin }\end{array}$} & \multirow{2}{*}{$\begin{array}{c}\text { Systems } \\
\text { tracts }\end{array}$} & \multicolumn{3}{|c|}{ 123-TH-1X Well in PK Basin } & \multicolumn{3}{|c|}{ 12W-HA-1X Well in NCS Basin } & \multicolumn{3}{|c|}{ PV-94-2X Well in TC-VM Basin } \\
\hline & & \begin{tabular}{|c|} 
Depth \\
(m)
\end{tabular} & Sediment & Environment & $\begin{array}{c}\text { Depth } \\
(\mathrm{m})\end{array}$ & Sediment & Environment & $\begin{array}{l}\text { Depth } \\
\text { (m) }\end{array}$ & Sediment & Environment \\
\hline \multirow{2}{*}{$\begin{array}{c}\text { Late } \\
\text { Miocene } \\
\left(\mathrm{N}_{1}{ }^{3}\right)\end{array}$} & HST & \multirow[t]{3}{*}{1300} & 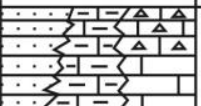 & Bay-Lagoon & \multirow[t]{3}{*}{1390} & 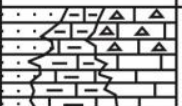 & Bay-Lagoon & \multirow[t]{3}{*}{750} & 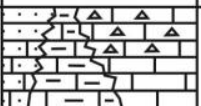 & Bay-Lagoon \\
\hline & TST & & 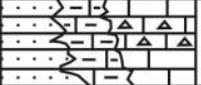 & Bay & & $\frac{5}{3.1}$ & Bay & & 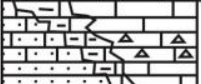 & Bay \\
\hline \multirow{4}{*}{$\begin{array}{l}\text { Middle } \\
\text { Miocene } \\
\left(\mathrm{N}_{1}^{2}\right)\end{array}$} & LST & & 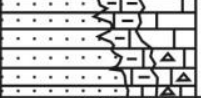 & Alluvium & & 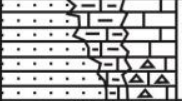 & $\begin{array}{l}\text { Alluvium } \\
\text { Delta }\end{array}$ & & 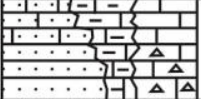 & Alluvial fan \\
\hline & HST & \multirow[t]{3}{*}{1558} & 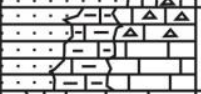 & Gulf & \multirow[t]{3}{*}{2269} & 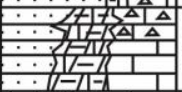 & Gulf & \multirow[t]{3}{*}{1660} & 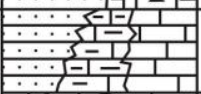 & Bay-Lagoon \\
\hline & TST & & 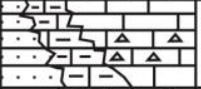 & Delta & & 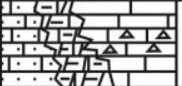 & $\begin{array}{l}\text { Shallow } \\
\text { marine }\end{array}$ & & 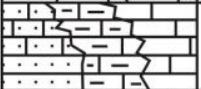 & Bay \\
\hline & LST & & 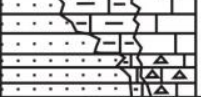 & Alluvium & & 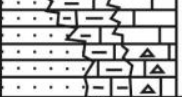 & $\begin{array}{l}\text { Alluvium } \\
\text { Delta }\end{array}$ & & 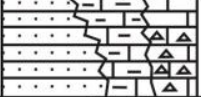 & Alluvial fan \\
\hline \multirow{3}{*}{$\begin{array}{c}\text { Early } \\
\text { Miocene } \\
\left(\mathrm{N}_{1}{ }^{1}\right)\end{array}$} & HST & \multirow[t]{3}{*}{2540} & 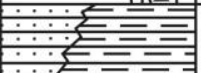 & $\begin{array}{l}\text { Shallow } \\
\text { marine }\end{array}$ & \multirow[t]{3}{*}{2564} & 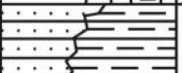 & $\begin{array}{l}\text { Shallow } \\
\text { marine }\end{array}$ & \multirow[t]{3}{*}{2460} & 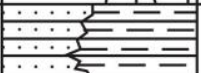 & $\begin{array}{l}\text { Shallow } \\
\text { marine }\end{array}$ \\
\hline & TST & & 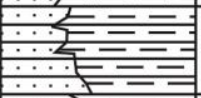 & Delta & & 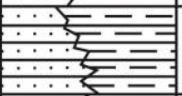 & Delta & & 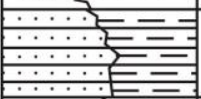 & Delta \\
\hline & LST & & $\therefore \bar{C}^{-}=-1$ & Alluvium & & $\because$ 年= & Alluvium & & $\because \bar{F}=$ & Alluvium \\
\hline
\end{tabular}

Legend:

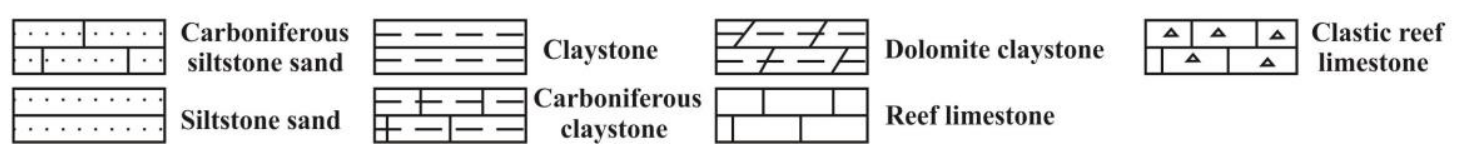

Figure 10. Comparison of Miocene lithologic characteristics in three wells 124-TH-1X, 12W-HA-1X and PV94-2X 


\begin{tabular}{|c|c|c|c|c|c|c|}
\hline \multicolumn{2}{|c|}{ Cycles } & \multicolumn{2}{|c|}{ Lithology } & \multirow[t]{2}{*}{ Sea level } & \multirow{2}{*}{\begin{tabular}{|c|}
$\begin{array}{l}\text { Quartz } \\
\text { content }(\%)\end{array}$ \\
$55-65$ \\
\end{tabular}} & \multirow[t]{2}{*}{ Sediment } \\
\hline \multirow{3}{*}{$\begin{array}{c}\text { Late } \\
\text { Miocene } \\
\left(\mathbf{N}_{1}^{3}\right)\end{array}$} & HST & $\begin{array}{l}\text { Slightly bioclastic } \\
\text { quartz sandstone }\end{array}$ & $\begin{array}{l}\text { Carboniferous } \\
\text { claystone }\end{array}$ & & & \\
\hline & TST & $\begin{array}{l}\text { Slightly bioclastic } \\
\text { quartz sandstone and } \\
\text { shallow marine foraminal }\end{array}$ & $\begin{array}{l}\text { Bay carboniferous } \\
\text { claystone }\end{array}$ & & $45-55$ & 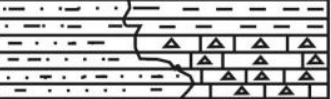 \\
\hline & LST & $\begin{array}{l}\text { Slightly bioclastic } \\
\text { quartz sandstone }\end{array}$ & $\begin{array}{l}\text { Bay slightly } \\
\text { carboniferous } \\
\text { claystone }\end{array}$ & & $40-45$ & 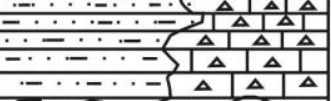 \\
\hline \multirow{3}{*}{$\begin{array}{l}\text { Middle } \\
\text { Miocene } \\
\left(\mathbf{N}_{1}^{2}\right)\end{array}$} & HST & Deltaic sandstone & $\begin{array}{l}\text { Bay slightly } \\
\text { carboniferous } \\
\text { claystone } \\
\end{array}$ & & $50-55$ & 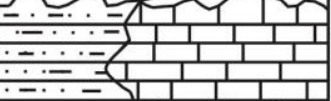 \\
\hline & TST & $\begin{array}{l}\text { Calcitic cement } \\
\text { sandstone }\end{array}$ & $\begin{array}{l}\text { Bay slightly } \\
\text { carboniferous } \\
\text { claystone } \\
\end{array}$ & & $45-50$ & 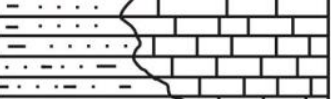 \\
\hline & LST & $\begin{array}{l}\text { Coastal alluvial } \\
\text { sandstone }\end{array}$ & $\begin{array}{l}\text { Bay slightly } \\
\text { carboniferous } \\
\text { claystone }\end{array}$ & & $35-45$ & 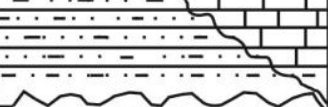 \\
\hline \multirow{3}{*}{$\begin{array}{c}\text { Early } \\
\text { Miocene } \\
\left(\mathbf{N}_{1}{ }^{1}\right)\end{array}$} & HST & Deltaic sandstone & $\begin{array}{c}\text { Bay slightly } \\
\text { carboniferous } \\
\text { claystone }\end{array}$ & & $45-55$ & 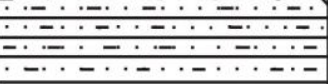 \\
\hline & TST & $\begin{array}{l}\text { Calcitic cement } \\
\text { sandstone }\end{array}$ & $\begin{array}{l}\text { Bay carboniferous } \\
\text { claystone }\end{array}$ & & $40-50$ & 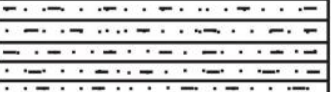 \\
\hline & LST & $\begin{array}{l}\text { Coastal alluvial } \\
\text { sandstone }\end{array}$ & $\begin{array}{c}\text { Bay slightly } \\
\text { carboniferous } \\
\text { claystone }\end{array}$ & & $35-45$ & $\begin{array}{r}-1 \\
\hdashline-1\end{array}$ \\
\hline
\end{tabular}

Legend:

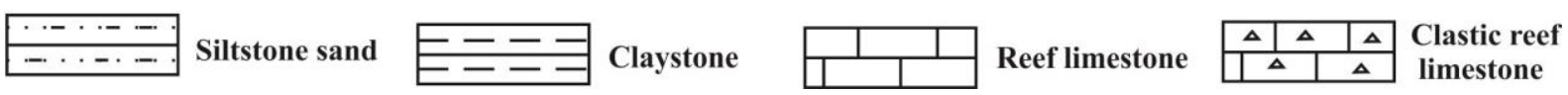

Figure 11. Summary of lithologic characteristics of three Miocene secondary basins in the Phu Khanh, Nam Con Son, Tu Chinh - Vung May basins

The depositional environment of sandstone was mainly fluvial deltaic and alluvial fans. Figure 12, well 12W-HA-1X at depth of 3580.8 $\mathrm{m}$ in Nam Con Son basin shows depositional composition consisting of litic-quartz sandstone with biological debris, fine grain, average sortness and roundness $(\mathrm{So}=1.9 ; \mathrm{Ro}=0.5)$, coastal tidal flat environment. In Tu Chinh Vung May basin, in LST stage of Miocene secondary basin at depth of $2320 \mathrm{~m}$ (well PV94$2 \mathrm{X})$ the litic-quartz sandstone with good sortness and average roundness $(\mathrm{So}=2.1$; $\mathrm{Ro}=0.5$ ) in the alluvial fans environment was encountered. Move to the upper part was the beginning of Trasgressive sequence (TST) that was characterized by parallel seismic wave configuration and downlap surfaces (Figure 12, 13). The depositional composition was liticquartz sandstone with biological clastic, fine grain, average sortness and average roundness $(\mathrm{So}=1.9 ; \mathrm{Ro}=0.5)$. The upmost part of sequence appeared carboniferous clay that was characterized for the lacustine environment encountered at the well $12 \mathrm{~W}-\mathrm{HA}-1 \mathrm{X}$, depth of $3411 \mathrm{~m}$. 


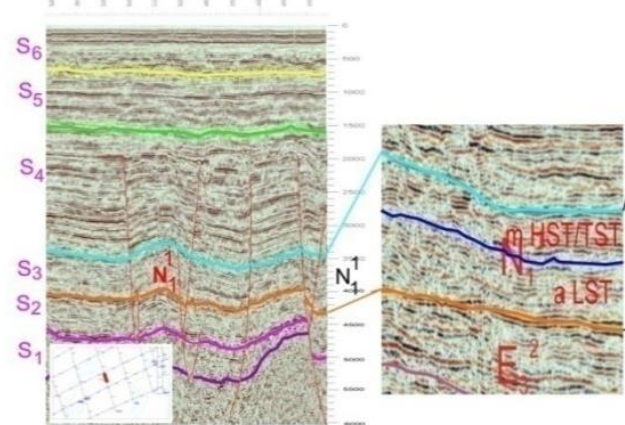

a. Seismic characteristics of early Miocene sequence in line S5 of Nam Con Son Basin.

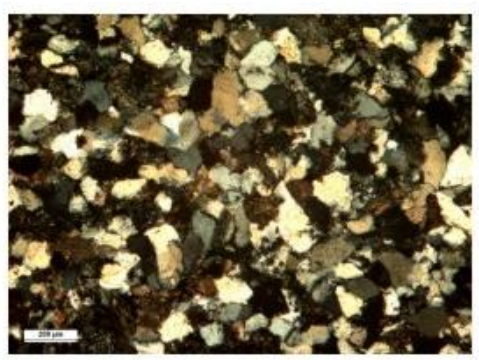

c. Arkose sandstone, fullfil cement, good sortness, average roundness, coastal tidal flat environment (Ro $=0.5 ;$ So $=1.8)($ Well $12 \mathrm{~W}-\mathrm{HA}-1 \mathrm{X})$, depth $3580,8 \mathrm{~m}), \mathrm{N}+, \mathrm{x} 40$.

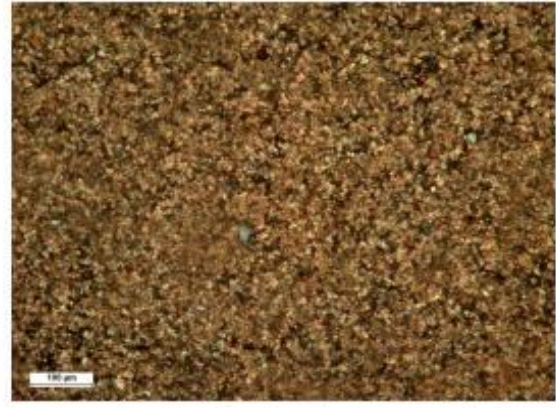

b. Claystone with fine grain, biological remains (algal), shallow bay-lagoon environment (well 12WHA-1X, depth $3411 \mathrm{~m}), \mathrm{N}+, \mathrm{x} 40$.

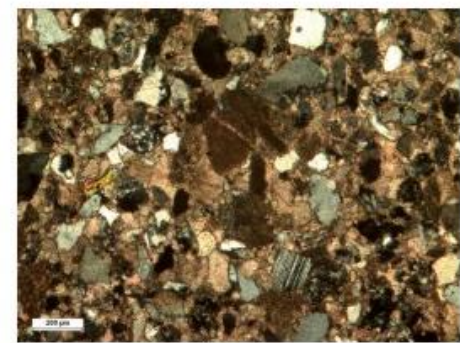

d. Graywacke sandstone, fine grain, basic cement rich in matrix, poor sortness and roundness, coastal marine environment (Well 12W-HA-1X, depth 3581.1m; Nam Con Son basin), N+, x40.

Figure 12. Depositional system tracts determined by seismic and lithologic data analysis of the early Miocene secondary basin in Nam Con Son basin
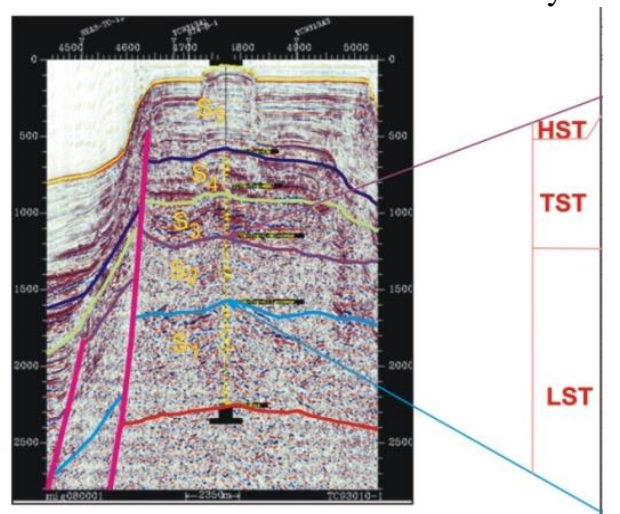

a. characteristics of early Miocene sequence in seismic line across the well PV94-2X.

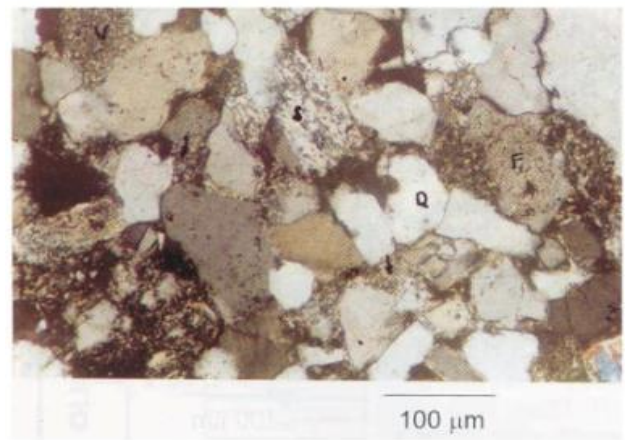

Quartz -litic sandstone, medium grain, average sortness, good roundness ( $\mathrm{So}=1.8 ; \mathrm{Ro}=0.6)$. Coastal tidal flat environment, (Well PV 94-2X), N+, x40.

Figure 13. Comparison of lithologic and seismic characteristics of the early Miocene secondary basin in Tu Chinh - Vung May basin. 


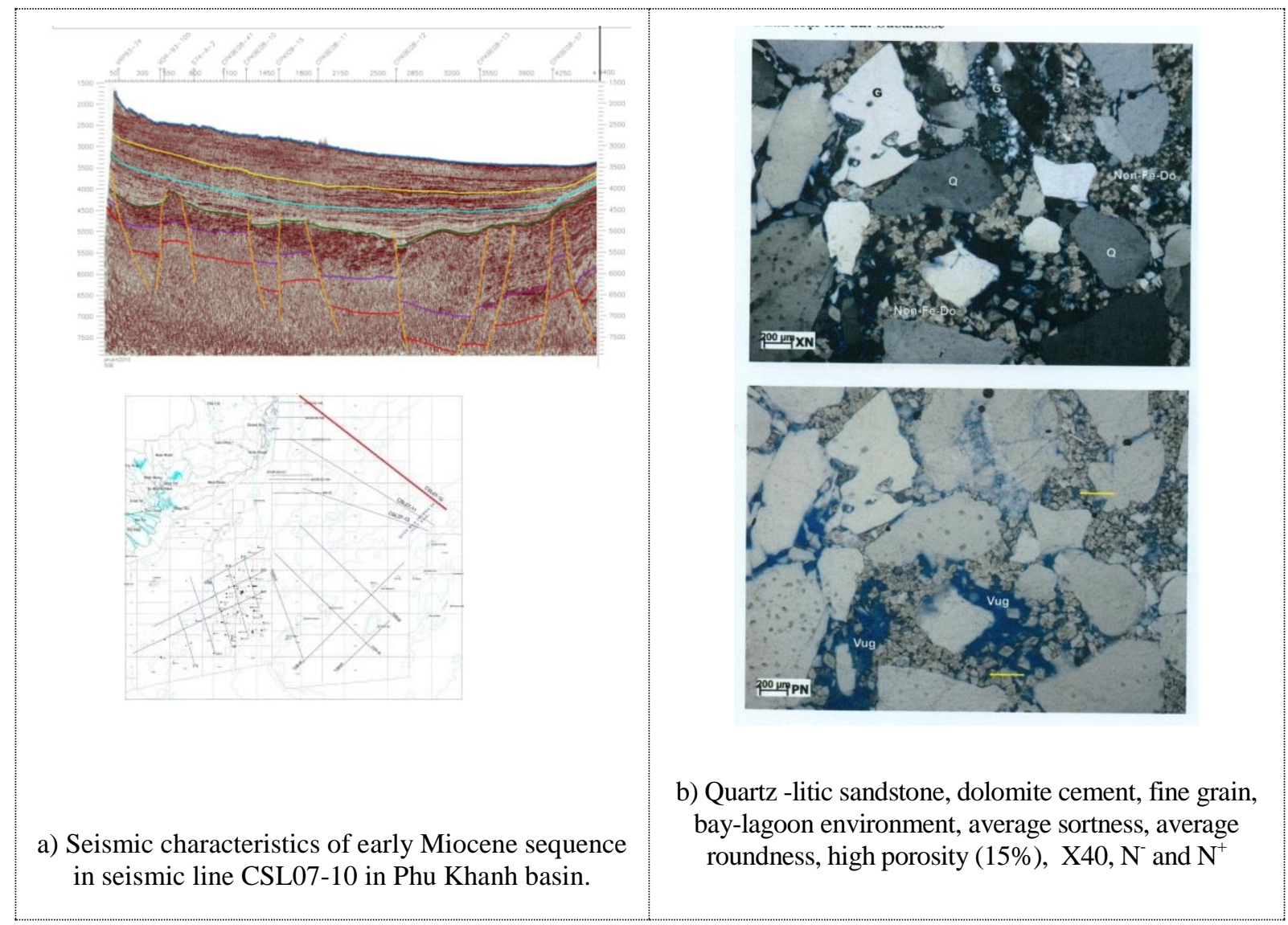

Figure 14. Comparison of lithologic and seismic characteristics of the early Miocene secondary basin in Phu Khanh basin.

b) Geological - sedimentary characteristics of middle Miocene $\left(\mathrm{N}_{1}^{2}\right)$

Geological characteristics: In middle Miocene, the geological structure plan of three basins was considerably changed. In the west of Phu Khanh and Nam Con Son, shelf structure is stable. In the center and in the east it mainly had even blocky shape due to effectiveness of strike-slip and rotation faults occurred before syndepositional normal fault. These blocks play the role of underground islands that were favorable for coral reef development (Figures $9 \mathrm{~b}$ and $15 \mathrm{~b})$.

Sedimentary characteristics: in the middle Miocene stage the deposition accumulation space seems to be not changed in comparison with the early Miocene stage. In the lower part of the middle Miocene secondary basin, that corresponds to the Lowstand System Tract (LST), the rate of terrigenous deposition were higher than carbonate. The terrigenous deposits were distributed nearly the eroded zone and characterized by arkose sandstone with poor roundness $(\mathrm{So}=2.3, \quad \mathrm{Ro}=0.4)$ belonging to fluvial environment. Quartz-litic sandstone with average to good sortness and average roundness deposited in tidal flat environment. In the center of middle Miocene secondary basin in the regressive stage, it started developing carboniferous claystone and bitumen claystone in bay-lagoonal environment (Figures 16, 17, 18). Therefore, the rate of carbonate rock development was higher than the terrigenous depositional rocks. 


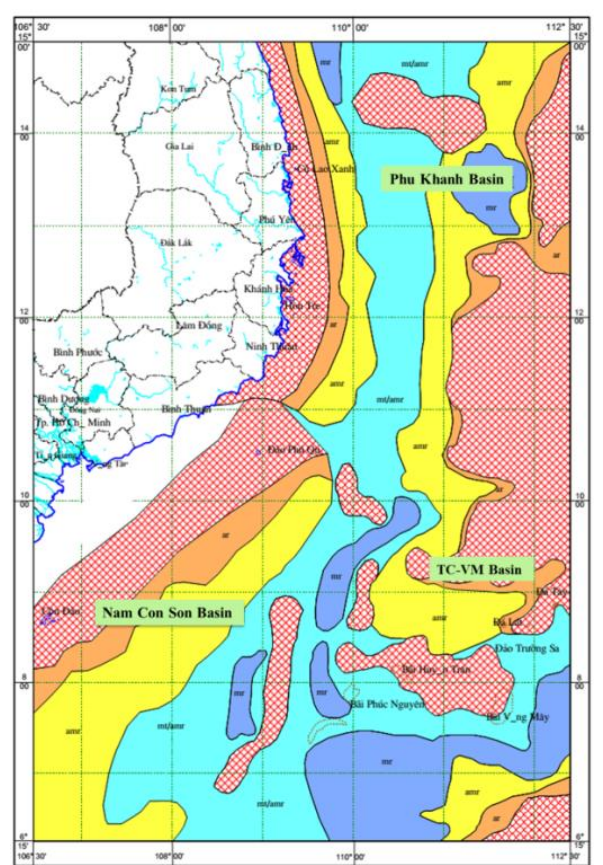

a) Lithofacies-paleogegraphical schema in the beginning period of early Miocene

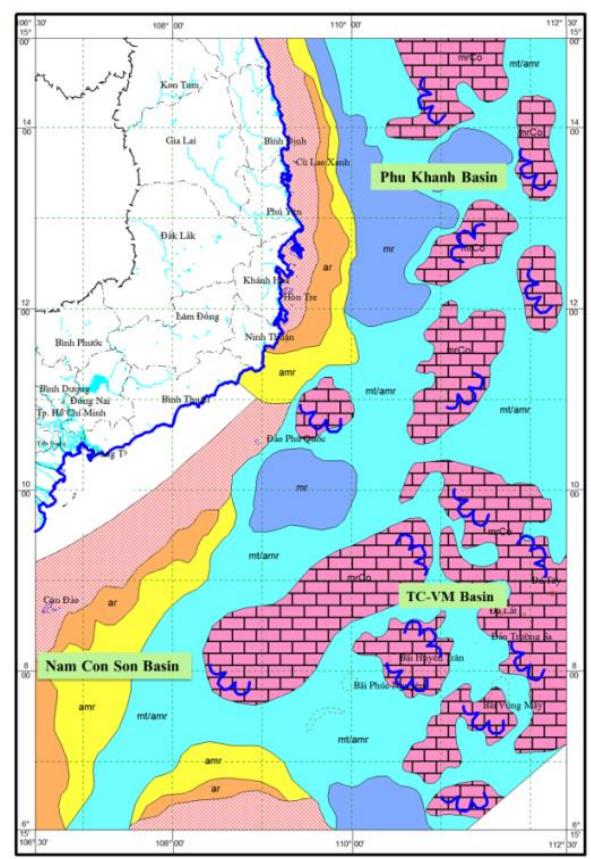

b) Lithofacies-paleogeographical schema in the beginning period of middle Miocene

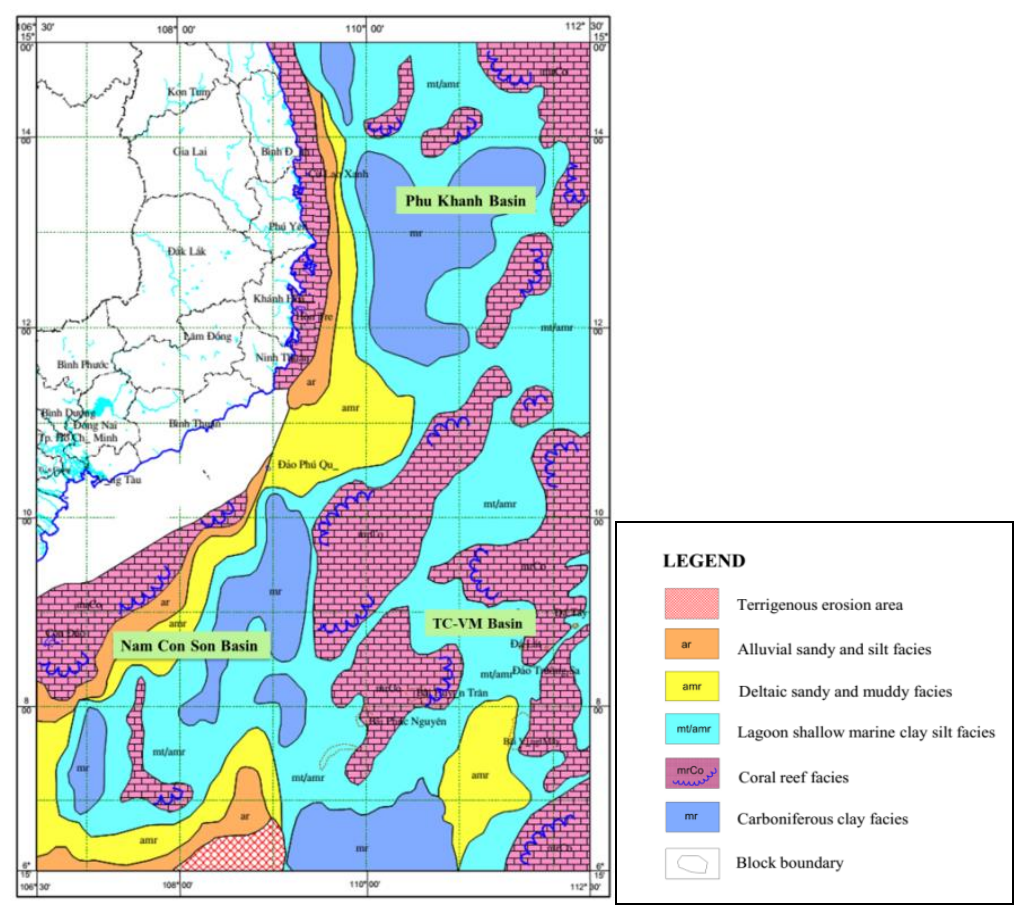

c) Lithofacies- paleogeographical schema in the beginning period of late Miocene

Figure 15. Lithofacies-paleogeographical schema in the beginning period of early, middle, late Miocene stages corresponding to Lowstand System Tract (LST) in the basins. 
For Nam Con Son and Tu Chinh - Vung May basin there were much more dolomite limestone with turbidity type structure due to bottom current in the semiclosure bay- lagoon environment with $\mathrm{pH} \geq 9$. In the middle TST and upmost HST sequences of the middle Miocene secondary basin, the rate of carbonate development was higher than the terrigenous

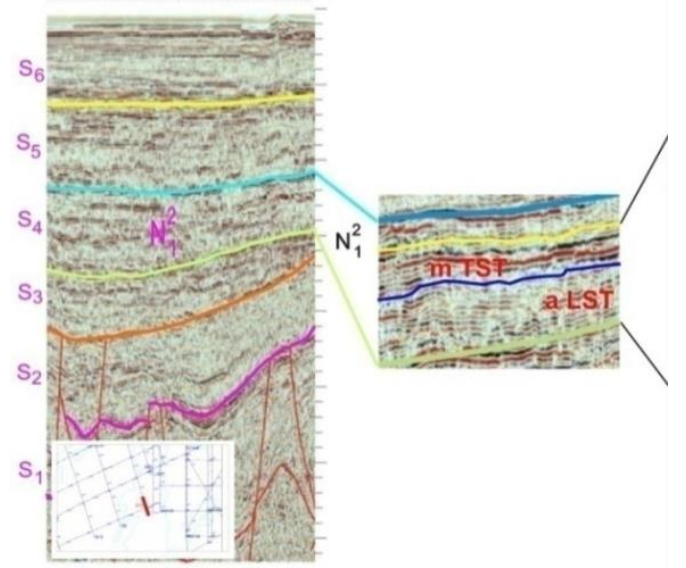

Seismic characteristics of early Miocene sequence on the seismic line S5 in Nam Con Son basin

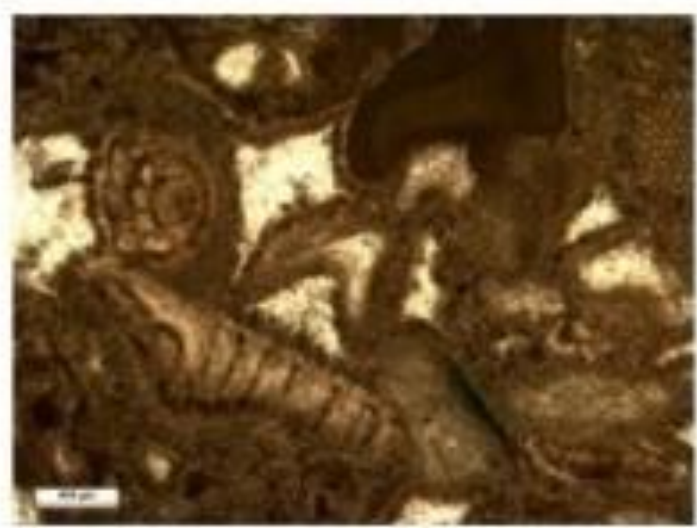

Fine grain limestone with quartz sand, well-preserved biological debris, TST, middle Miocene sequence $\left(\mathrm{N}_{1}^{2}\right)$; Well 06-A-1X, depth 2495.1m, N+, x40 sedimentary rate in all three basins. Only for Tu Chinh - Vung May basin, coral reef facies was strongly developed on the underground islands with higher rate than in early Miocene. It proved that the tectonic regime in this stage was relatively stable, depositional accumulation and subsidence processes were occurred relatively regularly (Figure 18, 19).

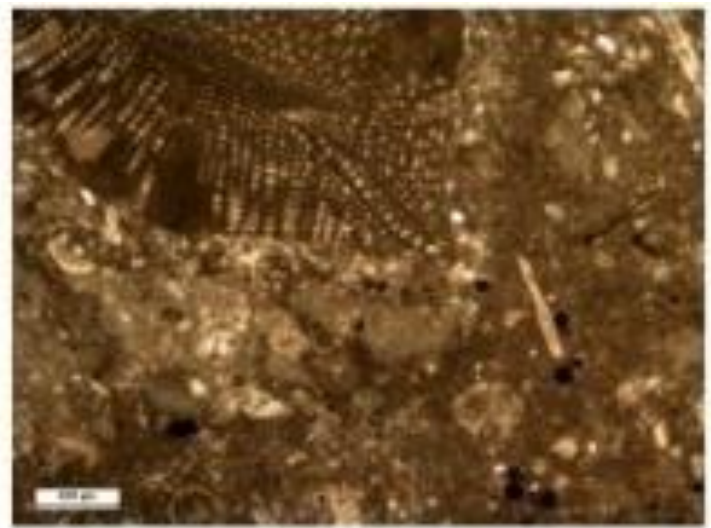

Limestone derived from coral reefs, micro calcite, coral texture remain about $15 \%$ (Well 06-A-1X, depth $2495.1 \mathrm{~m}), \mathrm{N}+\mathrm{x} 40$

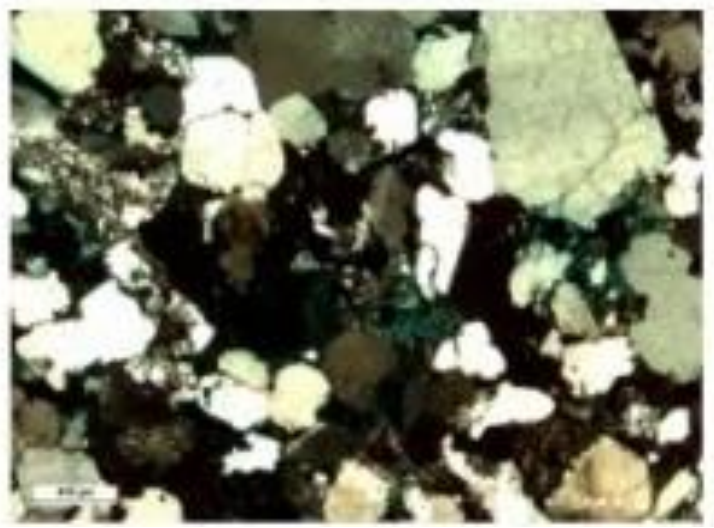

Quartz-litic sandstone, poor sortness, good roundness, tidal flat environment with relative strong wave, middle Miocene sequence $\left(\mathrm{N}_{1}^{2}\right)$, Well 06-A$1 \mathrm{X}$, depth $3893,8 \mathrm{~m}, \mathrm{~N}+$, x40

Figure 16. Comparison of lithologic and seismic characteristics of the middle Miocene secondary basin in Nam Con Son basin. 


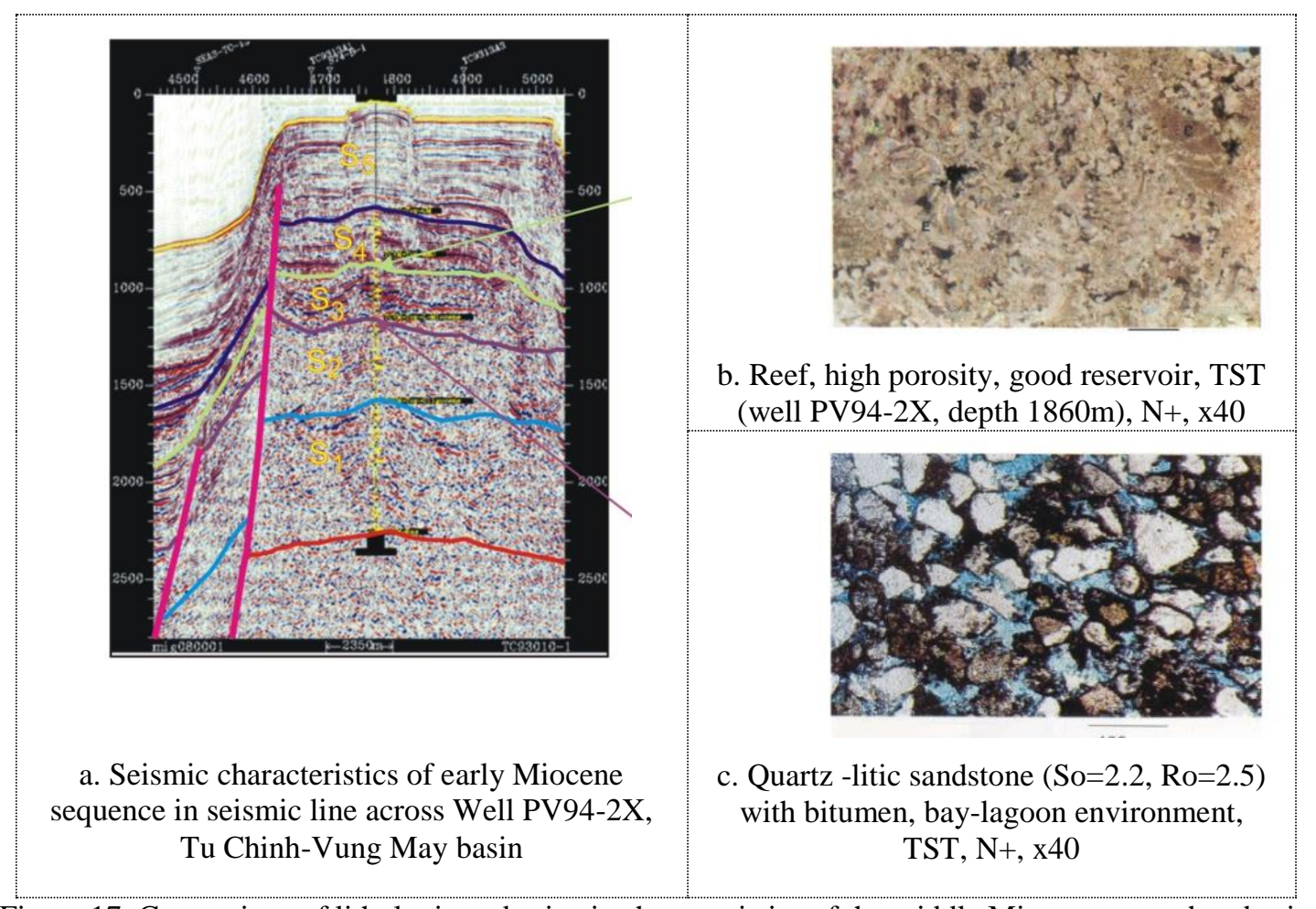

Figure 17. Comparison of lithologic and seismic characteristics of the middle Miocene secondary basin in Chinh - Vung May basin

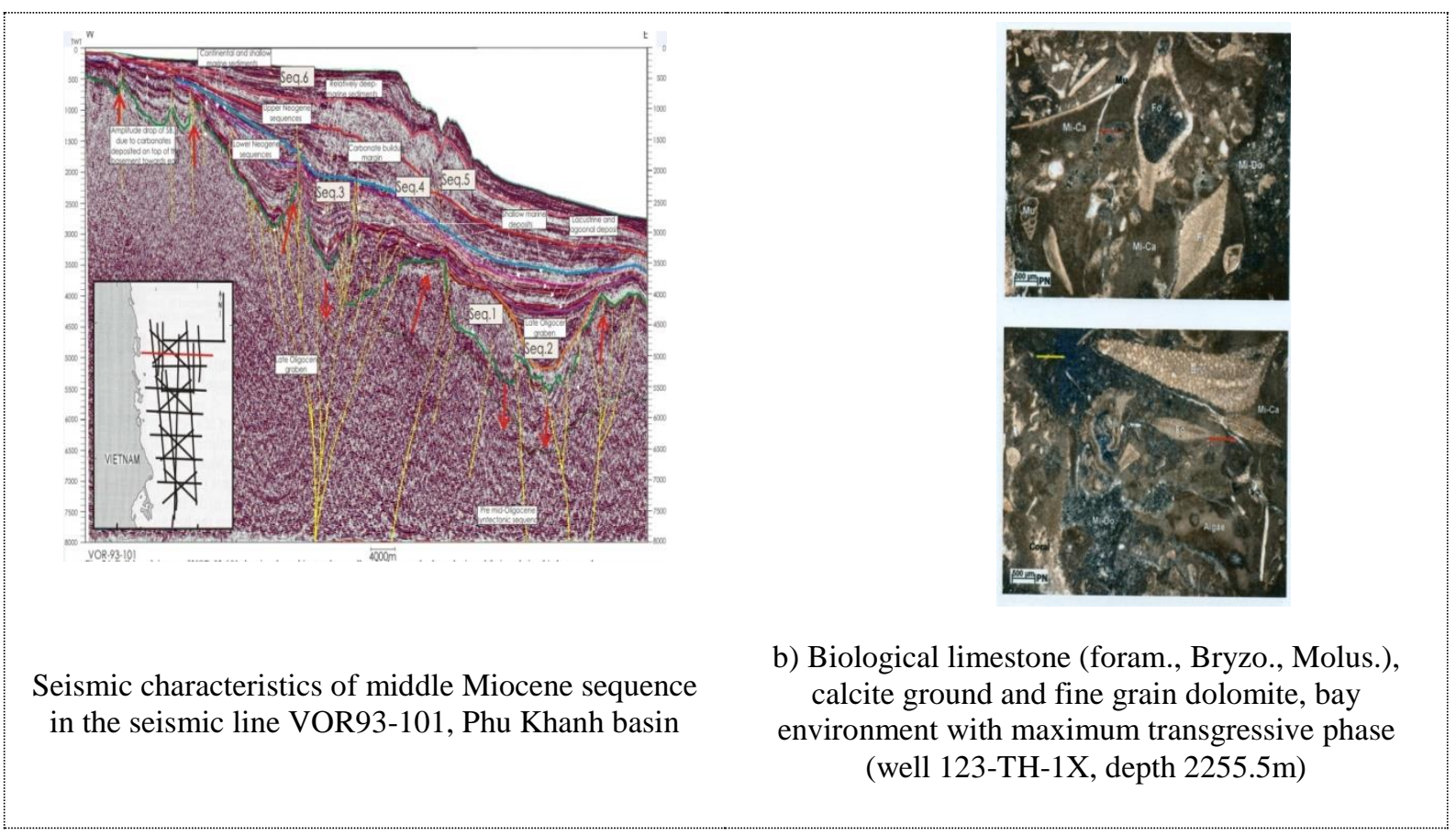

Figure 18. Comparison of lithologic, seismic and well logging characteristics of the middle Miocene secondary basin in the well 123-TH-1X and on the seismic section VOR93-101 in Phu Khanh basin 
c) Geological and depositional characteristics of late Miocene $\left(\mathrm{N}_{1}{ }^{3}\right)$

Geological characteristics: The late Miocene sequences of Phu Khanh and Nam Con Son basins were formed in two uplift zones: one in the west and one in the outer uplift zone. The subdsidence zone was located in the central zone. Only for Phu Khanh basin, the boundary between outer and inner shelf was step type subsidence zone along the $109^{\circ}-110^{\circ} \mathrm{E}$ syndepositional fault system. All three basins were located in the general tectonic setting and developed in two periods: (1) the first period to near the end of late Miocene, the central area and outer uplift zone had differentiated movement and blocky. The coral reef islands were uplifted over the sea level, resulting to create the eroded zones to supply biological sedimentary materials to the subsidence blocks that were interbedded lagoons (Figure 9c, 15c).

Sedimentary characteristics: In late Miocene, the uplifted terrain and hydraulic zones were lessened in comparison with the ones in the middle Miocene. The coral reefs uplifted over sea level, eroded and flattened to supply a large amount of coral, biological debris and quartz clastics in lowstand phase (LST). To the transgressive phase, the biological debris sediments with terrigenous quartz were brought to shallow marine environment under the impact of base carboniferous muddy current flow in mixture with terrigenous materials of marginal environment to create the composite rocky group as biological debris sandstone with quartz (Figures 19, 20). In the seismic sections of the figures 7, 8 in Phu Khanh and Tu Chinh Vung May basin, it was shown that late Miocene sequence was characterized by the free reflection wave field. It was folded and uplifted in the anticlinal shape due to effect of uplift and compression process occurred in late Miocene.

In the late Miocene stage, the ratio of carbonate rocks was still more dominated than terrigenous rocks, formed a complex rock group and distributed regularly in all areas of three basins and it was considered as a remark layer of biological debris rock group with migrated terrigenous clastics (Figures 19, 20).

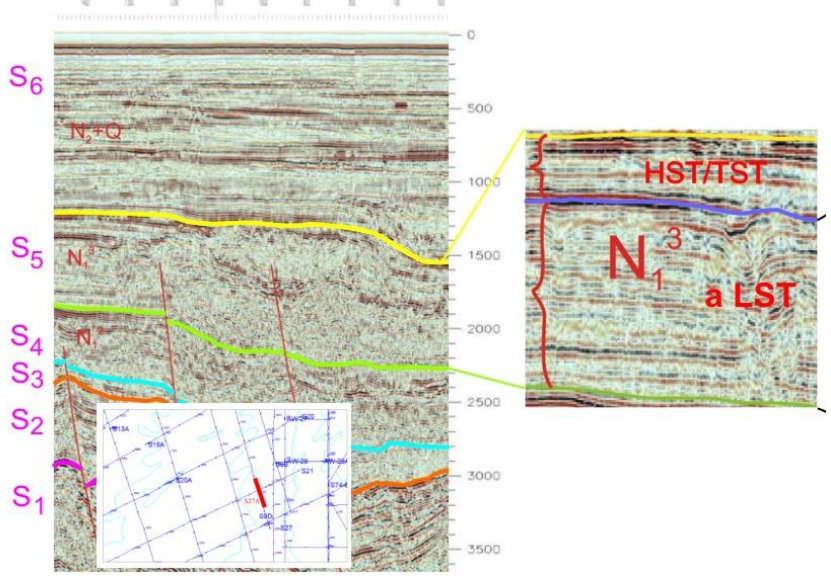

Seismic characteristics of late Miocene sequence on the seismic line S5 in NCS basin

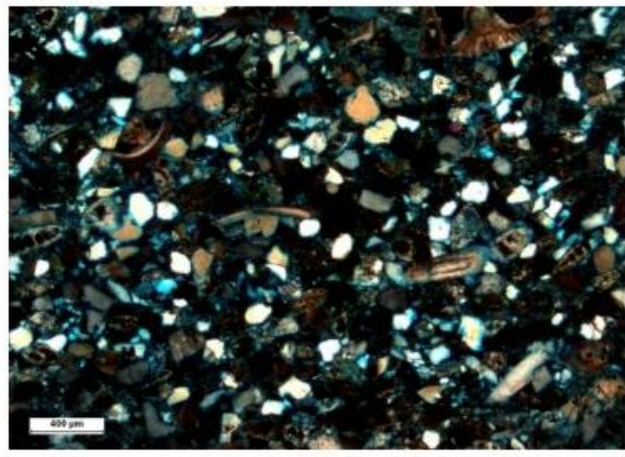

b) Quartz felspat sandstone with biological debris, fullfil cement, average to good roundness, average sortness (Well 05-1C-DH1X, depth 1390m) 


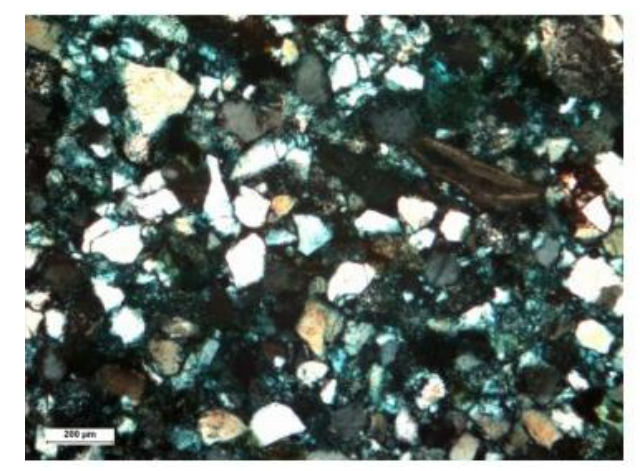

c) Quartz sandstone, full -basic cement, rich in matrix (organic matter, fine clastic partical) (Well 05-1C-DH-1X, depth 1680.1m).

Figure 19. Comparison of lithologic and seismic wave characteristics of the late Miocene secondary basin in Nam Con Son basin.

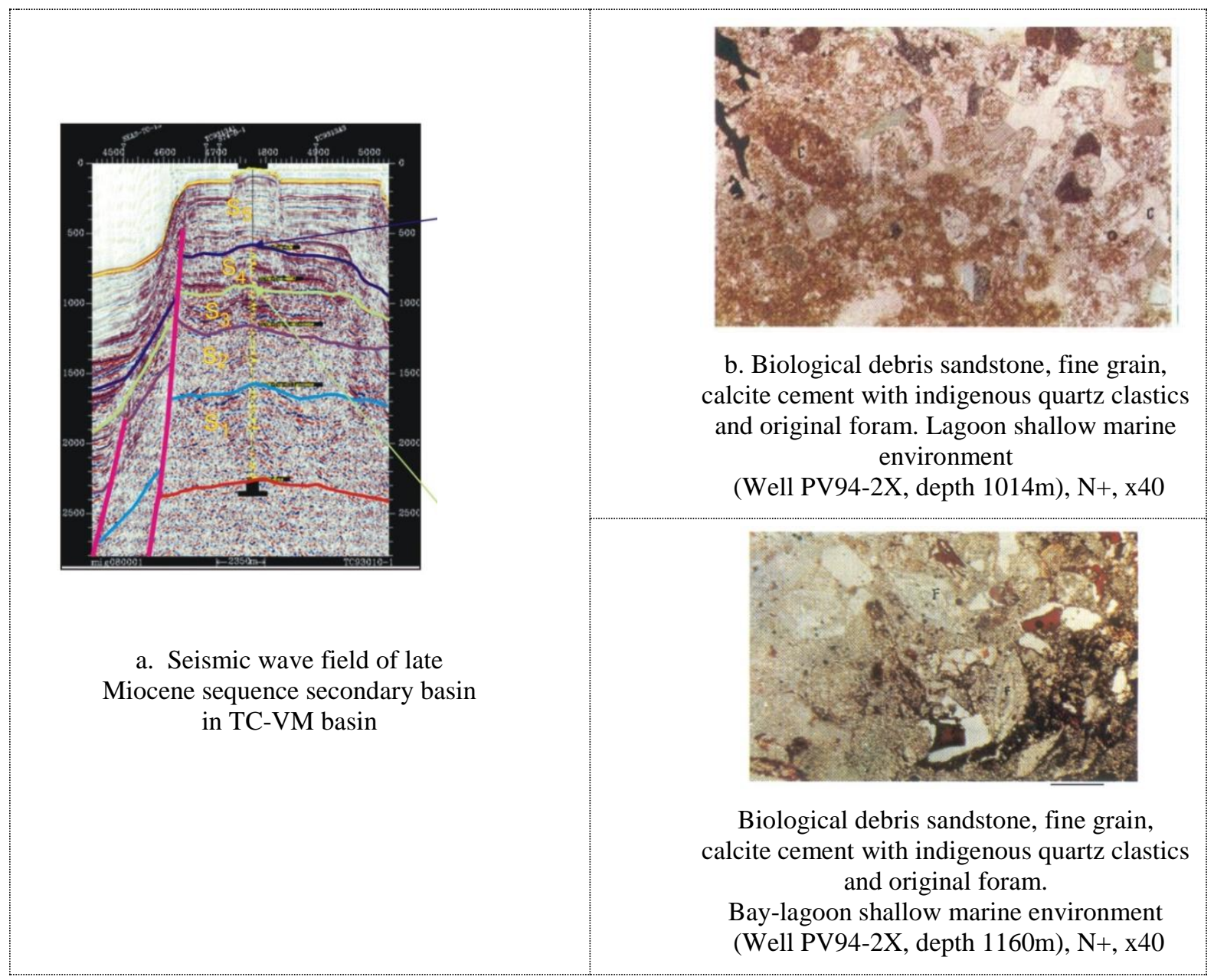

Figure 20. Comparison of lithologic and seismic wave characteristics of the late Miocene secondary basin in Tu Chinh - Vung May basin 


\section{Conclusions}

1- The deposits in the area of Phu Khanh, Nam Con Son and Tu Chinh - Vung May basins were developed in three cycles corresponding to three depositional sequences as early, middle, late Miocene and had the cause-consequence relation with eustatic sea level change and tectonic movement.

2- The beginning with each cycle in the basin is the thermal subsidence process differentiated to create a group of depressions. The subsidence process to create the secondary basins had formed the syndepositional and symmetric normal fault system in the interior of the basin. Subsidence process was occurred at the same time with transportation and sedimentary compensation processes. As a result, the secondary basin was also completed and the clastic deposits had undergone the diagenesis stage with the original forming structure.

3- At the end of each cycle, the early, middle, late Miocene secondary basins were compressed, extended, uplifted and created the eroded surfaces and fault systems with different levels of 2,3. They were strike-slip, reverse, inclination wing normal fault, strike sliprotation faults.

4- The schema of geological structure of each secondary basin was established based on the original isopach maps (reconstructed) to reappear the lithofacies-paleogeographical picture for the secondary basins. Based on that it is possible to recognize the cause consequence relationship between sedimentary thickness and the tectonic subsidence amplitude. In the depocenters of Phu Khanh, Nam Con Son and Tu Chinh - Vung May basins with the greatest depositional thickness, it means that there the tectonic subsidence amplitude was also the greatest and characterized by dominated submarine deltaic terrigenous depositional facies.

5- The early Miocene deposits mainly are terrigenous clastics as graywacke sandstone, arkose sandstone, quartz-litic sandstone belonging to alluvial sandy facies, tidal flat sand facies and bay-lagoonal carboniferous clay facies. The terrigenous clastics have 2 origins to supply: (1) from Oligocene uplift with composition of almost terrigenous rocks, that played the role of the eroded zone to supply the materials; (2) from the large eroded zones in the west of Phu Khanh basin, in the west and southwest of Nam Con Son basin (NCS uplift zone) and in the southeast of Tu Chinh - Vung May basin.

6- The middle Miocene deposits are typically consisted of three groups: (1) terrigenous rocks as quart-litic sandstone, shallow marine cement calcite sandstone derived from the eroded zones to be islands aged early Miocene (with terrigenous composition) and othe eroded zones as similar as the early Miocene stage; (2) The reef carbonate group was developed on the underground islands aged early Miocene; (3) The composite rock group includes carboniferous claystone, bitumen bearing claystone, carboniferous silt sand formed in the hydraulic lagoons in Transgressive phase.

7- The late Miocene deposits are basically consisted of three groups: (1) the biological debris sandstone group includes biological debris sandstone bearing quartz of coastal marginal environment and original foraminifera, fine grain, calcite cement of shallow marine environment. They are products of eroded processes and fattened processes of coral reef islands aged middle Miocene; (2) the coral reef rock group developed continuously on coral reef underground islands aged middle Miocene; (3) the carboniferous claystone group, dolomite limestone, bitumen bearing claystone formed in the half-closure hydraulic baylagoons with $\mathrm{pH} \geq 9$.

8- The Miocene deposits in the modern deep water area of the basins were changed in comply with three cycles of lithofacies association corresponding with three cycles of eustatic sea level change (LST, TST and HST). From one lithofacies group (terrigenous facies) in early Miocene it was developed into two 
facies groups (terrigenous and carbonate mainly reef carbonate) in middle Miocene and three facies groups (terrigenous, biological clastic sand and reef carbonate) in late Miocene.

9. According to the diversification of depositional facies, mineral composition of sandstone was simpler and simpler: multimineral sandstone in Miocene was progressively changed into little minerals in middle and late Miocene.

\section{Acknowledgements}

The authors would like to thank the Petrovietnam and Hanoi University of Science for permission to use the data concerning with the content of the paper. Special thanks go to the Vietnam National Project numbered KC.09.20/11-15 belonging to the Important Scientific and Technology Programme of State Level for helful comments and improvements of first vevise of this paper.

\section{References}

[1] Ngo Thuong San, Le Van Truong, $\mathrm{Cu}$ Minh Hoang, Tran Van Tri, 2007. Vietnamese tectonics in the structural frame of South East Asia. Geology and petroleum resources. Sci. and Tec. Publising house (in Vietnamese).

[2] Nguyen Nhu Trung, Nguyen Thi Thu Huong, 2003. Crustal structure of the Earth in East Sea by gravity anomaly and deep seismic data, proceeding of Scien. And Tech. Conference.

[3] Fyhn, M.B.W., Boldreel, L.O., Nielsen, L.H., 2009. Geological development of the Central and South Vietnamese margin: Implications for the establishment of the South China Sea, Indochinese escape tectonics and Cenozoic volcanism. Tectonophysics 478, pp. 184-214.

[4] Tran Nghi, 2010. Sedimentology in geological marine and petroleum. Publishing house of VNU Hanoi (in Vietnamese).

[5] Tran Nghi, Tran Huu Than, Chu Van Ngoi, Dinh Xuan Thanh, Tran Thi Thanh Nhan, Nguyen Thi Huyen Trang, Nguyen Duy Tuan, Nguyen Van Kieu, Tran Thi Dung, Nguyen Thi Phuong Thao, Pham Thi Thu Hang, Tran Van Son, 2013.
Cenozoic depositional evolution of Phu Khanh basin in relation to tectonic activity. Geological journal, series A, No 334, pp 28-36 (in Vietnamese).

[6] Tran Nghi, Chu Van Ngoi, Tran Thi Dung, 2013. Lithofacies analysis and reconstruction of deformation types of Cenozoic sediments of Phu khanh basin. VNU Journal of Earth and Environmental Science, Vol. 29; No.1; (2013) 4556 (in Vietnamese).

[7] Rukhin L. B, 1969. Basic Sedimentology, Publishing House, Moscova, 1969 (in Russian).

[8] Dickinson W. R., and Suczek, C. A., 1979. Plate tectonics and sandstone composition. Am. Assoc. Petroleum Geologists Bull. 63.

[9] DickinsonW. R., 1985. Interpreting provenance relations from detrital modes of sandstones. In: Zuufa, G. G. (Ed). Provenance arenites. Dordrecht: D Reidel Pub. Co., Ser. C 148, 333362.

[10] Gerhard Einsele, 1991. Sedimentary basins. Springer-Verlag.

[11] Tran Nghi, Dinh Xuan Thanh, Tran Thi Thanh Nhan, Pham Thi Thu Hang, Tran Thi Dung, 2013. Advance sedimentology in Cenozoic basin analysis in Vietnam deep Sea water. Geological Journal, series A, No 336-337, 7-10/2013, pp 1323 (in Vietnamese).

[12] H. W. Posamentier, M. T. Jervey, P. R. Vail, 1988. Eustatic controls on clastic deposition IConceptual framework. Sea-Level Changes - An Integrated Approach, SEPM Special Publication No.42, The Society of Economic Paleontologists and Mineralogists, ISBN 0-918985-74-9.

[13] Emery D. and Myers K.J., 1996. Sequence stratigraphy. Blackwell science, BP exploration, stockley Park Uxbridge, London.

[14] Catuneanu. O., 2006. Principles of sequence stratigraphy. Department of Earth and Atmospheric sciences - University of Alberta, Canada.

[15] Tran Nghi, Tran Huu Than, Dinh Xuan Thanh, Tran Thi Thanh Nhan, Tran Thi Dung, 2014. Deformation of Cenozoic secondary basin in Phu Khanh basin area and related petroleum potentials. VNU Journal of Science, Natural sciences and Technology, Vol.30, No 2S, 2014; pp 1-11 (in Vietnamese).

[16] Nguyen Trong Tin, Tran Nghi and et al., 2013. Geological structure and hydrocarbon potential of Cenozoic basins in Vietnam continental shelf, Proceeding of Sci. And Tec. Conference, Sci. and Tec. Publishing house (in Vietnamese). 
[17] Tran Nghi, Chu Van Ngoi, Tran Thi Dung, Dinh Xuan Thanh, Tran Thi Thanh Nhan, Pham Thi Thu Hang, 2014. Research on Cenozoic lithological evolution of Tu Chinh - Vung May basin in relation to sea level change and tectonic activity, VNU Journal of Science, Natural sciences and Technology, V.30, No 2S, 2014, pp 101-110 (in Vietnamese).

[18] Pham Bao Ngoc, Tran Nghi, 2016. Characteristics of Sequence stratigraphy of Miocene deposits in Nam Con son basin. VNU Journal of Science, Natural science and Technology, V.30. No 1.

[19] Longley Ian M., 1997. Tectonostratigraphic evolution of S. E. Asian. Petroleum geology of S. E. Asia.

[20] Tran Nghi, Tran Thi Dung, Pham Thi Thu Hang and et al., 2014. Study of sequence stratigraphy in Tu Chinh - Vung May area. Journal of Sciences and Technology, Ministry of Science and Technology, No19, pp 58-64.

[21] Chu Van Ngoi, Tran Nghi and et al., 2015. Mechanism of formation and evoluation stages of
East Sea. Journal of Science and Technology, Vol 3 , No3, ISSN 1859-4794; pp. 27-32 (in Vietnamese).

[22] Le Van $\mathrm{Cu}$, Hoang Ngoc Dang, Tran Van Tri, 2007. Mechanizm of formation and types of Cenozoic sedimentary basins in Vietnam, Sci. and Tec. Publising house (in Vietnamese).

[23] Philip A. Allen \& John R. Allen, 1990. Basin analysis. Blackwell Scientific Publications Editorial iffices. Osney Mesd, Oxford OX2 OEL.

[24] Nguyen Hoang, Phan Trong Trinh, 2009. Summary of lithologic and geochemical charactyeristics of Neogene - Quaternary rocks and Mantle dynamic in East Sea and neighbor areas, Geological Journal, 312, pp. 39-57 (in Vietnamese).

[25] Tran Huu Than, Tran Nghi, Tran Thi Dung, Pham Thi Thu Hang, 2013. Evaluation of hydrocarbon potential of Phu Khanh basin based on the study of tectonic mechanism and geodynamic of the basins. Preceesing of Sci. and tec. conference, Sci. and Tec. Publishing house (in Vietnamese).

\title{
Lịch sử phát triển địa chất trầm tích Miocen khu vực bể Phú Khánh, Nam Côn Sơn và Tư Chính -Vũng Mây thềm lục địa Việt Nam
}

\author{
Trần Thị Dung ${ }^{1}$, Trần Nghi $^{2}$, Nguyễn Thế Hùng ${ }^{1}$, \\ Đinh Xuân Thành ${ }^{1}$, Phạm Bảo Ngọcc ${ }^{3}$, Nguyễn Thị Tuyến ${ }^{2}$, \\ Trần Thị Thanh Nhàn ${ }^{1}$, Nguyễ் Thị Huyền Trang ${ }^{1}$ \\ ${ }^{1}$ Trường Đại học Khoa học Tự nhiên, ĐHQGHN, 334 Nguyễn Trãi, Hà Nội, Việt Nam \\ ${ }^{2}$ Viện nghiên cứu Địa Môi trường và Thích ưng Biến đổi Khi hậu \\ ${ }^{3}$ Trường Đại học Dầu khí, Tập đoàn Dầu khi Việt Nam
}

Tóm tắt: Lịch sử phát triển địa chất trầm tích Miocen của 3 bể Phú Khánh, Nam Côn Sơn và Tư Chính -Vũng Mây thuộc vùng biển nước sâu thực chất là tiến hóa trầm tích trong mối quan hệ với sự thay đổi mực nước biển và chuyển động kiến tạo. Trầm tích Miocen cả 3 bể đều có 3 chu kỳ trầm tích tương ứng với 3 phức tập: 1/ Phức tập Miocen sớm: Bối cảnh kiến tạo của 3 bể tương đối giống nhau. Thời kỳ này địa hình ít phân dị, môi trường trầm tích chủ yếu là aluvi, ven biển và biển nông vũng vịnh. Địa hình đáy bể của nóc Miocen sớm bị biến dạng bởi các quá trình kiến tạo như: nén ép, nâng lên, uốn nếp, đứt gãy và phân dị tạo ra địa hình gồ ghề nổi cao và bào mòn. Sản phẩm của quá trình bào mòn là cung cấp vật liệu lục nguyên cho các thủy vực Miocen sớm dưới dạng vũng vịnh. 2/ Phức 
tập Miocen giữa: Bối cảnh kiến tạo bắt đầu thay đổi. Các bể phân dị thành 2 nửa: Thềm trong cấu trúc địa chất bình ổn, trầm tích lục nguyên thống trị; Thềm ngoài sụt lún mạnh hơn, địa hình đáy phân dị gồ ghề phát triển 2 kiểu trầm tích: Trầm tích lục nguyên chứa carbonat và carbonat ám tiêu. $3 /$ Phức tập Miocen muộn: Vào đầu chu kỳ các bể phân dị thành 2 đới cấu trúc rõ rệt: đới phía tây có địa hình nghiêng thoải ổn định, trầm tích lục nguyên thống trị và đới phía đông có địa hình phân dị mạnh, phát triển các quần đảo ám tiêu san hô đóng vai trò là vùng xâm thực cung cấp một khối lượng lớn vật liệu trầm tích vụn sinh vật cho các vũng vịnh nông.

Từ khóa: Tiến hóa trầm tích, bể thứ cấp, phục hội, tướng đá. 